Georgia State University

ScholarWorks @ Georgia State University

Spring 5-5-2012

\title{
Smartphone Apps on the Mobile Web: An Exploratory Case Study of Business Models
}

Caroline Morgan Ford

Follow this and additional works at: https://scholarworks.gsu.edu/bus_admin_diss

\section{Recommended Citation}

Ford, Caroline Morgan, "Smartphone Apps on the Mobile Web: An Exploratory Case Study of Business Models." Dissertation, Georgia State University, 2012.

doi: https://doi.org/10.57709/3472495

This Dissertation is brought to you for free and open access by the Programs in Business Administration at ScholarWorks @ Georgia State University. It has been accepted for inclusion in Business Administration Dissertations by an authorized administrator of ScholarWorks @ Georgia State University. For more information, please contact scholarworks@gsu.edu. 


\section{PERMISSION TO BORROW}

In presenting this dissertation as a partial fulfillment of the requirements for an advanced degree from Georgia State University, I agree that the Library of the University shall make it available for inspection and circulation in accordance with its regulations governing materials of this type. I agree that permission to quote from, to copy from, or publish this dissertation may be granted by the author or, in his/her absence, the professor under whose direction it was written or, in his absence, by the Dean of the Robinson College of Business. Such quoting, copying, or publishing must be solely for the scholarly purposes and does not involve potential financial gain. It is understood that any copying from or publication of this dissertation which involves potential gain will not be allowed without written permission of the author.

Caroline Morgan Ford 


\section{NOTICE TO BORROWERS}

All dissertations deposited in the Georgia State University Library must be used only in accordance with the stipulations prescribed by the author in the preceding statement.

The author of this dissertation is:

Caroline Morgan Ford

5522 Stonewall Road

Little Rock, Arkansas 72207

The director of this dissertation is:

Pam Scholder Ellen

Department of Marketing

J. Mack Robinson College of Business

Georgia State University

PO Box 3989

Atlanta, GA 30302-3989 
Smartphone Apps on the Mobile Web: An Exploratory Case Study of Business Models

BY

Caroline Morgan Ford

A Dissertation Submitted in Partial Fulfillment of the Requirements for the Degree

Of

Executive Doctorate in Business

In the Robinson College of Business

Of

Georgia State University

GEORGIA STATE UNIVERSITY

ROBINSON COLLEGE OF BUSINESS

2012 
Copyright by

Caroline Morgan Ford 2012 


\title{
ACCEPTANCE
}

This dissertation was prepared under the direction of the Caroline Morgan Ford Dissertation Committee. It has been approved and accepted by all members of that committee, and it has been accepted in partial fulfillment of the requirements for the degree of Executive Doctorate in Business in the J. Mack Robinson College of Business of Georgia State University.

\author{
H. Fenwick Huss, Dean
}

\section{DISSERTATION COMMITTEE}

\author{
Pam Scholder Ellen \\ Steve W. Edison \\ Edward E. Rigdon
}


Smartphone Apps on the Mobile Web:

An Exploratory Case Study of Business Models

Caroline Morgan Ford

The purpose of this research is to explore the business strategies of a firm seeking to develop and profitably market a mobile smartphone application to understand how small, digital entrepreneurships may build sustainable business models given substantial market barriers. Through a detailed examination of one firm's process to try to commercialize their mobile app, we identify various business model decisions and marketing strategy approaches that hindered the company's efforts. The case study describes two distinctly different business models adopted in succession, as well as the various adjustments the firm makes to its target market, distribution and pricing approach that led to their current strategy. This research looks closely at business-to-business-to-consumer distribution arrangement for mobile apps and in doing so challenges the rising positive bias that exists for the app store as the dominant actor in the mobile value chain. For practice, this paper suggests unanticipated hurdles small digital entrepreneurs may face if they rely heavily on mobile advertising and the app store to launch and sustain their business.

August 2, 2012

Committee Chair: $\quad$ Pam Scholder Ellen

Major Academic Unit: Robinson College of Business 


\section{Table of Contents}

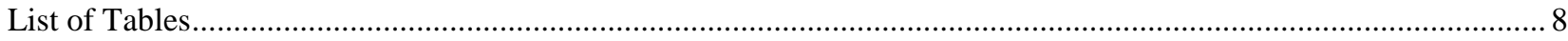

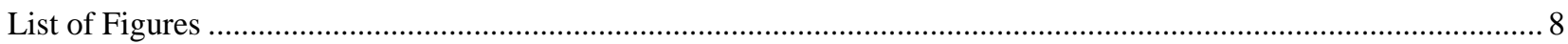

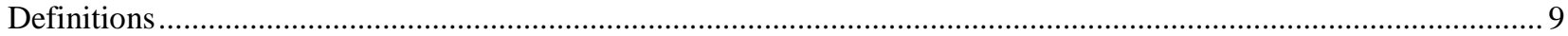

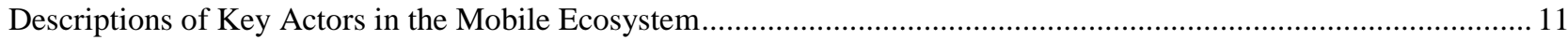

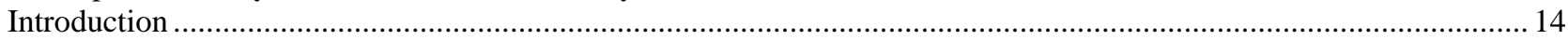

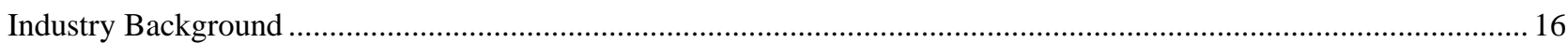

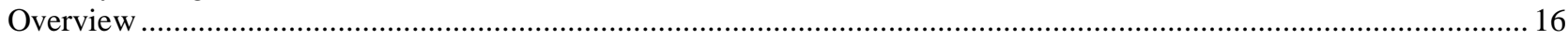

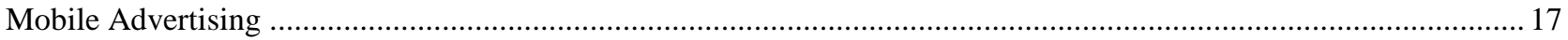

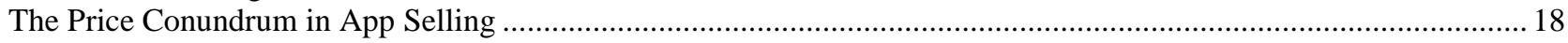

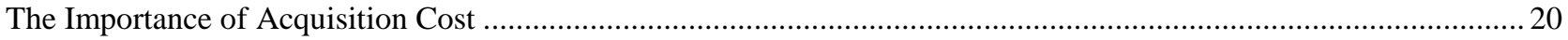

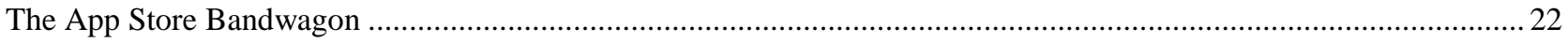

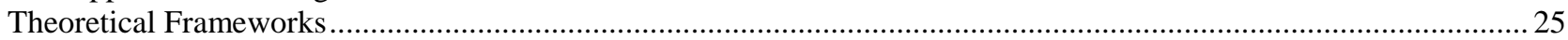

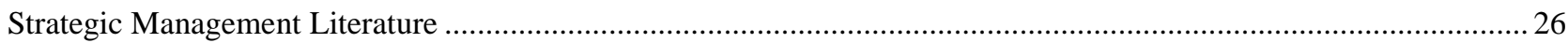

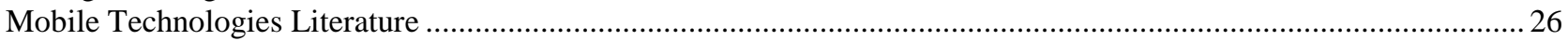

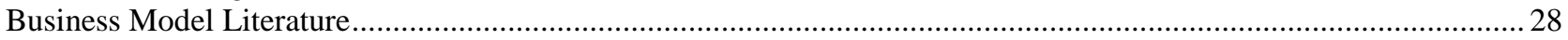

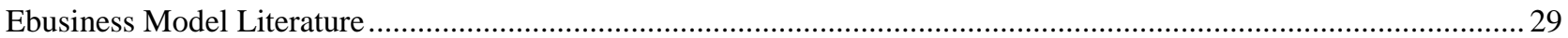

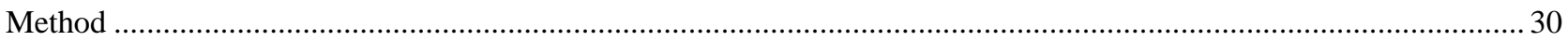

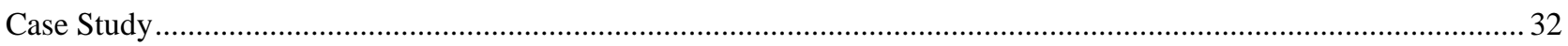

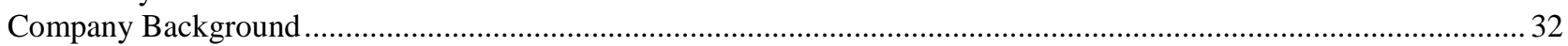

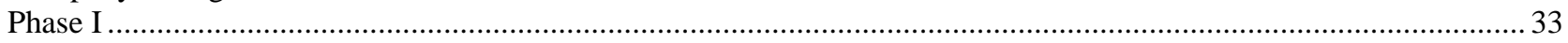

Target Marketing, Channel Choice and Pricing Approaches in Phase I...................................................... 35

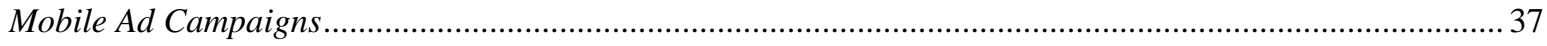

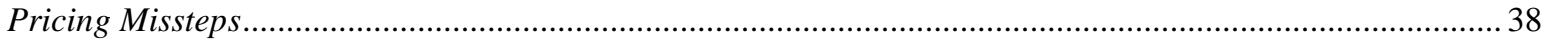

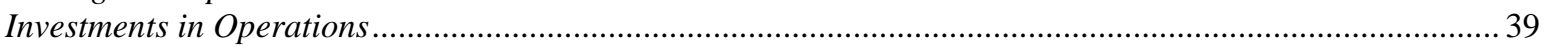

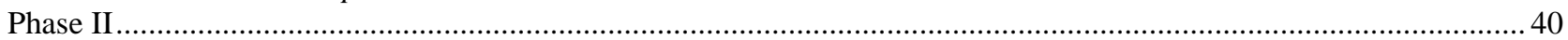

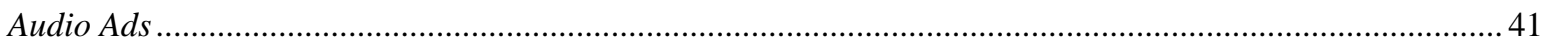

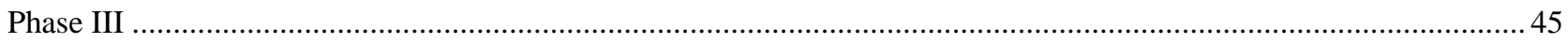

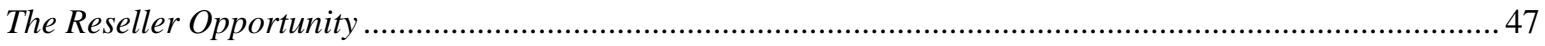

Product Positioning Adjustments: Scaling Down the App for a New Demographic ................................................... 47

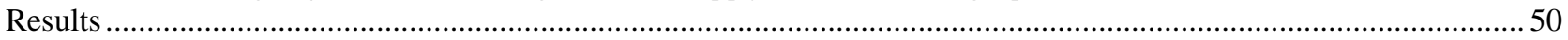

The B2B2C or Reseller Arrangement Lowers Customer Acquisition Costs 20-fold ...................................................50

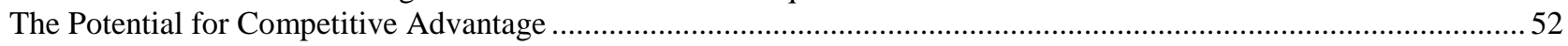

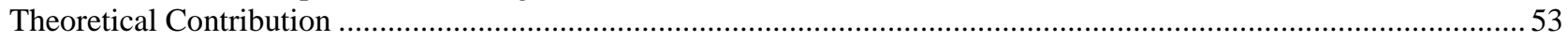

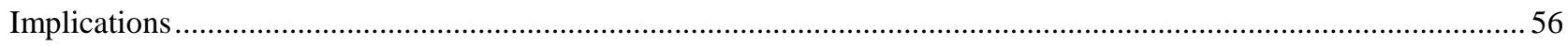

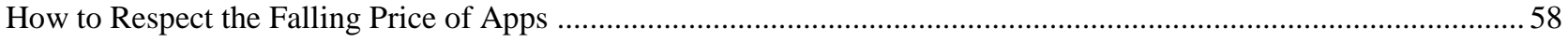

How to Leverage Mobile Network Operators or Other Actors in the Mobile Value Chain ..........................................59

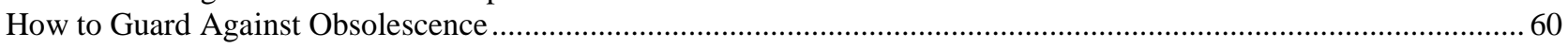

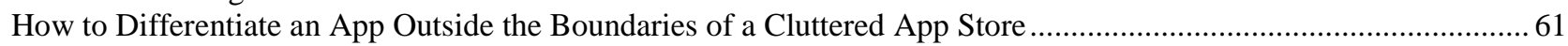

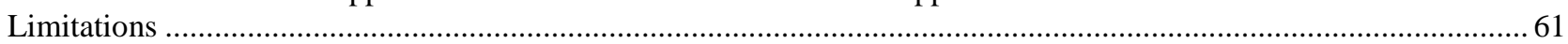

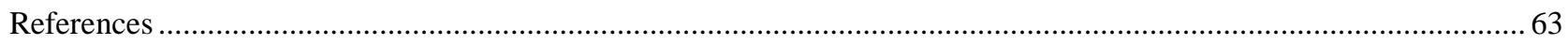

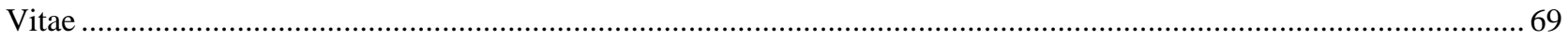




\section{List of Tables}

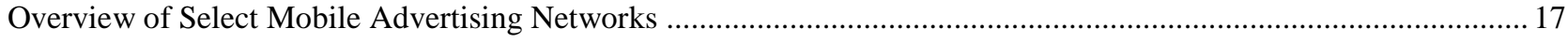

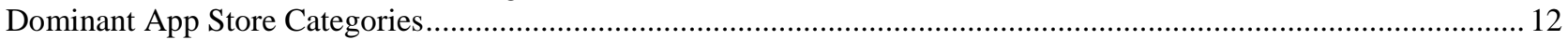

Smartphone Operating System 2012 and 2016 Market Share .............................................................................. 13

Samples of Registration Fees Required to Register Apps in Major App Stores......................................................... 16

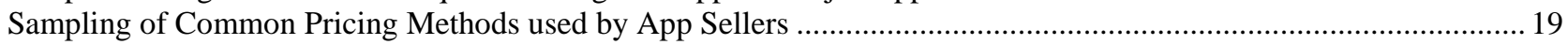

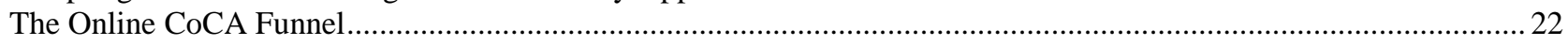

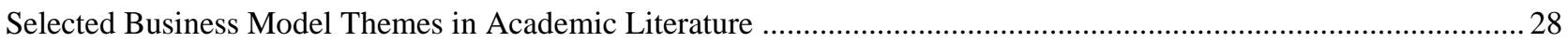

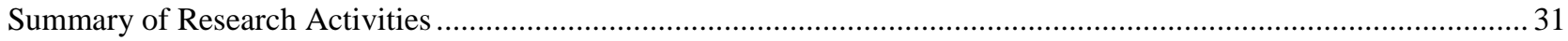

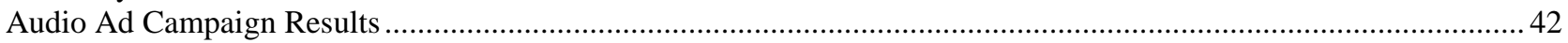

Summary of Early (Business Model 1) and Later (Business Model 2) Approaches .....................................................50

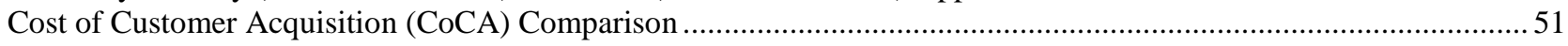

Preliminary Results: MNO1 Registrations, Customer Adds and New Totals ......................................................52

Applying Amit and Zott's Value Driver Dimensions to GuardIT Business Models ..................................................... 54

\section{List of Figures}

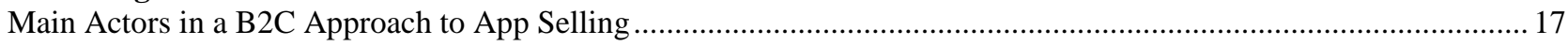

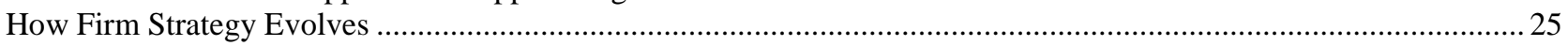

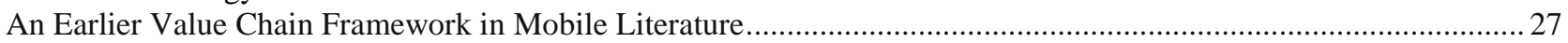

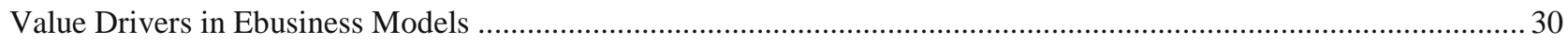

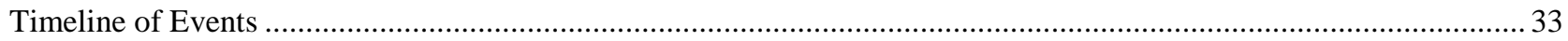

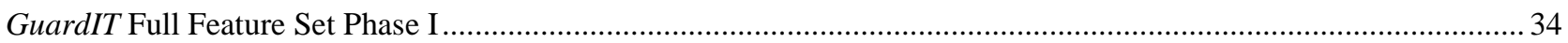

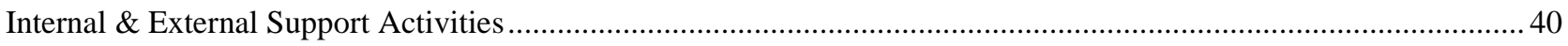

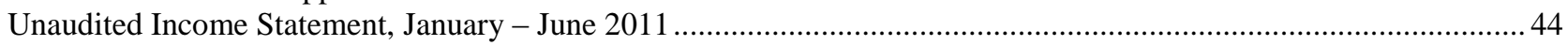

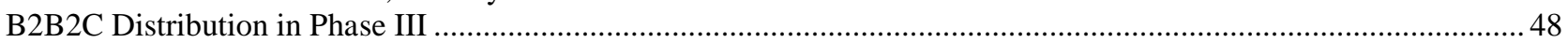

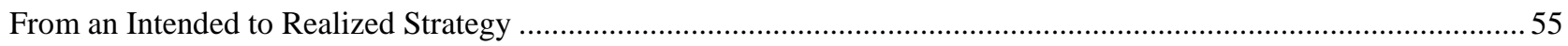

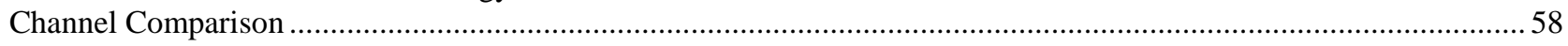

\section{List of Exhibits \& Appendices}

Exhibit 1 - Ad Network Reporting Sample of Campaign Performance ……............................................................ 67

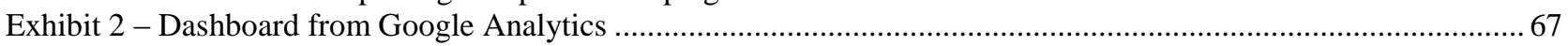

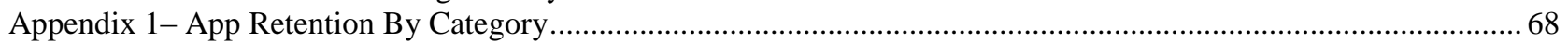




\section{Definitions}

App: an abbreviated or slang term for computer software application. This study focuses on applications written for mobile smartphone devices.

Business model: the individual blueprint for how the firm expects to deliver customer value or "make money" from its products or services. Performing business models in the context of this study are those that produce positive financial results or those that show a trend toward positive financial results.

Business-to-consumer (B2C) or direct-to-consumer (DTC): A distribution approach whereby the company markets products or services directly to end-users. In B2C distribution arrangements, sellers target communication messages to the end-user.

Business-to-business-to-consumer (B2B2C): A distribution approach whereby the company sells products or services to end-users by partnering with consumer-oriented or customer-facing firms. Often the originator of the product or service relies on the customer-facing company to promote and sell to the end-user. Both firms receive benefits from the reseller arrangement.

Customer Acquisition Costs or Cost of Customer Acquisition (CoCA): the firm's cost to acquire a single customer. CoCA formulas usually take into account the lifetime value of a customer (CLV) or the cost of a customer spread over a given period of months or years. In the mobile app context, CoCA may be calculated using a variety of costs which include mobile advertising costs, app store commissions or credit card processing fees.

Digital Entrepreneurship: a type of entrepreneurship in which the product or service is digitized rather than physical. A digital entrepreneurship as an entrepreneurial venture having digitalization factors derived from: 1) the digital nature of the firm's good or service, 2) the digital distribution potential of a good or service, 3 ) the potential digital interactions with key external stakeholders within the value chain, and 4) the digital potential of virtual internal activities associated with a firm's operations" (Esmaeeli, 2011).

Feature phones: scaled-down handsets or mobile phones which may offer web access but house a limited number or type of apps such as wallpaper or ringtone apps.

Free: The term "free" in this study designates an app that is perpetually free or offered at no or zero cost to the end-user.

Free trial offer: This term is used to describe a window of time during which an app may be downloaded and used at no charge to the end-user. Trial offers may aim to entice end-users in the short-term hopes that they will pay for the app at a future date.

Freemium: This term is used to describe pricing model used by app sellers to garner revenue from an app that may be initially positioned as "free" to end-users. Typical freemium scenarios include 1) certain versions of the mobile app are free, such as scaled-down versions that are less robust 2) the case where some end-users or customers may be paying for the app or supporting the firm's revenue stream while the bulk of others are enjoying the app at no cost (cross-subsidizing) and 3) a scenario 
where certain features, levels or tiers of the app are "free" but the app seller charges for other content, or special privileges.

Online Advertising: an overall category of advertising which uses "Internet-based technologies and data collection mechanisms to target and track specific individuals and to automate the buying and of advertising inventory" (Evans, 2009). Online ads, which include search, text, display or video ads, may run on desktop, smartphone, tablet, kiosks or other types of touchscreens or mobile web or interactive devices. The particular focus of this study is mobile web display advertising which, according to IDC, accounts for 30 percent of the total mobile advertising market (2011). Mobile search continues to account for the majority or 70 percent of the \$2.1 billion spent in the US on mobile advertising (IDC, 2011). Common terms in online advertising include:

1) CPC (Cost Per Click) or PPC (Pay Per Click) or PPF (Pay Per Performance) or CPA (Cost per Acquisition): a category of performance-based online advertising in which the publisher or host site assumes the risk of running the ad. Advertisers pay for advertisements only when the user clicks on an ad listing, downloads or installs an app or takes some other action in response to the offer. In this advertising rate structure, advertisers are not charged for the number of impressions or the number of people who see the ad. Instead, advertisers are charged only when consumers click and are redirected to another mobile or online website. This structure allows advertisers to refine searches and gain information about their market over time. By comparing click-thru performance rates across varying ad campaigns, advertisers can determine which types of ads may be more effective. This method may require other transactions such as requiring the end-user to sign-up or download an item after the click. Advertisers pay only for installations or only for the number of users who complete another transaction. For mobile app sellers, these models may measure end-user registrations or device downloads as an indicator of performance.

2) CPM (Cost per thousand): a method of charging for online advertising whereby advertisers are charged a fixed price or price range for every 1,000 impressions.

3) CTRs (Click-thru Rates): a way of measuring the success of email, mobile or desktop campaigns such as banner ads. The rate is defined as the number of clicks on an ad divided by the number of times the offer is shown and is expressed as a percentage. For example, if a banner ad is delivered 100 times (100 impressions) and receives one click, then the clickthru rate for the advertisement would be 1 percent.

Smartphones: As compared to a feature phone, a smartphone device is a web-enabled mobile handset equipped with a keyboard, touchscreen tiles and large storage capacity for housing applications. 


\section{Descriptions of Key Actors in the Mobile Ecosystem}

Ad Networks: Ad networks connect advertisers with relevant audiences (publishers or web sites) and offer advertisers reporting mechanisms for how ads performed. Ad networks are the most common type of ad distribution intermediary. Mobile advertising networks connect advertisers and web sites or publishers to serve billions of mobile display, text and video ads each month to consumers across hundreds of models of smartphone devices. A mobile ad network is the entity that allows advertisers to advertise on mobile sites or within mobile apps. When an advertiser uses an ad network, the advertiser does not have to negotiate directly with the entity selling the advertising space. Google Admob, for example, collects and returns information to its advertising customers via its Google Analytics portal at www.googleanalytics.com. Advertisers can set-up dashboards or customized tracking of ad campaigns to learn the number of daily click, the sources of mobile traffic, conversion rates by source and other facts that gauge performance. (See Exhibits 1 and 2 for a sample report and Dashboard).

Blind ad networks are a specific category of mobile ad networks that serve a high volume of advertising to an extensive base of mostly independent mobile publishers such as mobile sites. Blind networks also supplement their ad inventory with premium publishers' unfilled inventory. Blind networks do not offer advertisers the choice of specific mobile sites to run their ads. Blind networks also offer cost-per-action (CPA) where advertisers specify the price they are willing to pay for each conversion.

Ad networks in mobile typically use revenue models similar to those originally developed for banner ads on the computer desktop. Popular online advertising fee structures for display ads are cost per thousand (CPM), or cost-per-click (CPC) which originated in 1996. Increasingly in online mobile advertising, advertisers are requesting a performance-based pricing structure. Ad networks typically specialize in the sale of premium, secondary premium or remnant ad space. Remnant or remainder ad space refers to online ad space that has gone unsold, either by the ad broker or the publisher. This means advertisers can buy what is typically expensive online advertising space for a significant discount because the ad space would not be sold otherwise. Table 1 outlines selected ad networks.

The ad distribution network in mobile is still a fragmented marketplace wherein estimates vary as to who holds the second, third, fourth and fifth place market share rank. IDC and others cite Google as the market leader in mobile display advertising in the US (2011) with approximately 60\% market share. Smaller competitors include Millennial Media, Apple, Yahoo!, Microsoft and Jumptap. 
Table 1: Overview of Select Mobile Advertising Networks

\begin{tabular}{|c|c|c|c|c|}
\hline Ad Network & $\begin{array}{l}\text { Estimated } \\
\text { Marketshare }\end{array}$ & $\begin{array}{l}\text { Estimated } \\
\text { Number of } \\
\text { Publishers } \\
\text { Served }\end{array}$ & $\begin{array}{l}\text { Estimated } \\
\text { Number of } \\
\text { Advertisers } \\
\text { Served }\end{array}$ & Price Structure \\
\hline AdMob (Google) & $59 \%$ & $100 \mathrm{~K}$ & $10 \mathrm{~K}$ & $\mathrm{CPC}$ or $\mathrm{CPM}$ \\
\hline iAd (Apple) & $8.7 \%$ & $<1000$ & 70 & Mixed \\
\hline Milenial Media & $6.8 \%$ & $>1000$ & 250 & $\begin{array}{l}\text { Advertisers can buy ads } \\
\text { on specific sites for a } \\
\text { premium fee. }\end{array}$ \\
\hline Yahoo Mobile & $5.6 \%$ & 2000 & 200 & Mixed \\
\hline $\begin{array}{l}\text { Jumptap, MSN Ad } \\
\text { Network } \\
\text { + Others }\end{array}$ & $\begin{array}{l}\text { Other } 19.9 \% \\
\text { marketshare } \\
\text { held by other } \\
\text { firms }\end{array}$ & & & Mixed \\
\hline
\end{tabular}

Source: IDC, 2011

App Stores: App (or application) stores are open marketplaces for buyers (consumers) and sellers (developers) of smartphone apps. App stores offer user-rating capability, a central payment mechanism and a support method by which consumers can download software to their mobile device. Mobile apps are marketed, paid for, disseminated and/or downloaded to the smartphone device via a variety of app store types including 1) the smartphone device manufacturer (eg Apple), 2) the operating system vendor (eg Google Android Market), 3) the network operator (eg ATT Central), or 4) the independent retail based category (eg Amazon Appstore). App stores take a commissioned percentage of revenue, such as 70:30 from the app seller (70 percent to the app maker and 30 percent to the seller). While many types of app stores exist, this study focuses on two dominant types of app stores being deployed by app sellers: 1) the smartphone device manufacturer app store and 2) the operating system vendor app store as outlined in Table 2.

Table 2: Dominant App Store Categories

\section{Mobile App Store Category}

1) Device manufacturer

2) Operating System Vendor

\section{Example(s)}

Apple App Store, Blackberry App World, Nokia

Ovi Store, Palm App Catalog, Samsung App

Store, LG Application Store

Google Android Market, Windows Marketplace, Java Store 
Device Manufacturers and Operating System (OS) Vendors: These are corporations manufacturing mobile devices and frequently the operating system that supports the devices' built-in software (firmware) and mobile applications. The most prevalent operating systems include those developed for Android, Windows 7/Windows Mobile, iPhone, and Blackberry devices. Table 3 shows IDC's current, projected and compounded annual growth rate for these manufacturers.

Table 3: Smartphone Operating System 2012 and 2016 Market Share

\begin{tabular}{|c|c|c|c|}
\hline Smartphone OS & $\begin{array}{c}2012 \text { Market } \\
\text { Share }\end{array}$ & $\begin{array}{c}2016 \text { Market } \\
\text { Share }\end{array}$ & $\begin{array}{c}2012-2016 \\
\text { CAGR }\end{array}$ \\
\hline Android & $61.0 \%$ & $52.9 \%$ & $9.5 \%$ \\
\hline Windows Phone 7/Windows Mobile & $5.2 \%$ & $19.2 \%$ & $46.2 \%$ \\
\hline $\mathrm{iOS}$ & $20.5 \%$ & $19.0 \%$ & $10.9 \%$ \\
\hline BlackBerry OS & $6.0 \%$ & $5.9 \%$ & $12.1 \%$ \\
\hline Others & $7.2 \%$ & $3.0 \%$ & $-5.4 \%$ \\
\hline Total & $100.0 \%$ & $100.0 \%$ & $12.7 \%$ \\
\hline
\end{tabular}

Source: IDC, 2012

End-user: In this study, end-user denotes the individual consumer or customer downloading mobile apps to his or her mobile smartphone device.

Mobile Network Operators (MNOs): The main role of operators is to implement and operate mobile networks that provide cellular or mobile service. These corporations may or may not own the network assets. Mobile operators maintain the direct relationship with the consumer making them powerful and established entities. They act as mobile service providers by owning the portal and the billing and service relationship with the customer. These companies provide the physical core mobile network infrastructure which comprises air interfaces, base stations, routers, switches and backbone transport technologies required to operate and manage the network. They are the infrastructure backbone of the channel.

Network Equipment Providers (NEV): This category consists of companies manufacturing the infrastructure and equipment needed to operate a mobile or wireless network. (GSM, EDGE)

Small Mobile Application Businesses $\left(S_{m} A B\right)$ : a term adopted for this study that refers to small firms, individuals or digital entrepreneurships who develop, market and service one or more mobile mobile apps for a profit.

Subscriber: Customers of mobile network operators or telecommunications carriers. 


\section{Introduction}

Growth in the smartphone market suggests the smartphone and its apps may be the preferred way to access the web in the future. In early 2012, more than 60 million Americans report owning a smartphone. Smartphone sales grew 42.7 percent worldwide in the second quarter of 2012 while smartphone handset sales represent a projected 72 percent share of growth in the future (Gartner Research, 2012). In a report on the top ten strategic technologies for 2012, Gartner forecasts there will be more than 70 billion app downloads from app stores every year beginning in 2014 (2011).

The rapid diffusion of smartphones and the increasing popularity of apps entice digital entrepreneurs and other types of technology start-ups to try to capitalize on the 'killer app' phenomena. After their app is accepted by a centralized app store where millions of users can access it, these firms are allured by the notion that financial rewards will result from "getting big fast". The makers of Instagram, for example, embody the "getting big fast" ideal by selling their photo-sharing application to Facebook in 2012 for an estimated \$1 billion.

Many types of firms hope to capitalize on the app phenomena. Some app start-ups are dedicated exclusively to mobile; only developing apps for smartphone platforms. Foursquare and Path, for example, are examples of this new breed of mobile apps where desktop versions of the application were never developed (Wortham, 2012, p. A1). The bulk of app ventures, however, are led by parttime technologists or less-seasoned professionals who are experimenting with writing mobile apps in their small office, dorm-room, home or garage.

In terms of their overall contribution to the economy, app development entrepreneurs and other app ventures in aggregate could represent 182,774 jobs and add more than 12 billion dollars to the US 
economy (University of Maryland, 2011). In sum, mobile apps and companies are a robust and growing sector; attracting 10 percent of the total investment dollars from American venture capital firms in the last quarter of 2011 (Wortham, 2012, p. A1).

The widespread appeal of mobile app development as a business venture can be seen in the number of independent individuals estimated to be writing apps today for major mobile platforms $(248,000$ registered for Apple; 270,000 for Android), the rapid increase in the number of apps housed in a given store (Apple >500,000), the rise in revenue earned by app stores and finally in the increase in consumer app downloads year over year. In March of 2012, Apple reported 25 billion total apps have been downloaded since the Apple app store opened in 2008 (2012).

The focus of this study is on the type of app development firm we label the " $S_{m} A B$ " or small application business in mobile. We define $S_{m} A B s$ as small technology start-ups or digital entrepreneurships dedicated exclusively to development apps for mobile smartphones. Usually selffunded, these ventures are attracted to the allure of app development as an opportunity to 'get big fast'. This allure is perhaps in part due to low barriers of entry including 1) the relatively small investment required to register a mobile app in an app store (See Table 1.1) 2) the short development time to get an app to market 3) the growing trend towards open operating systems (Campbell and Ahmed, 2011) and 4) the promise of the app store as an accessible, cheap and fast retail channel (Cortimiglia et al, 2011). 
Table 1.1: Samples of Registration Fees Required to Register Apps in Major App Stores

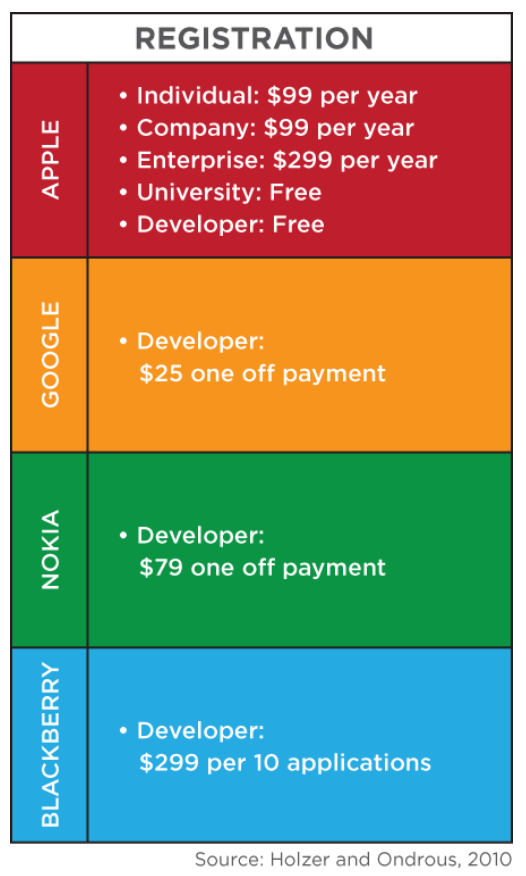

\section{Industry Background}

\subsection{Overview}

Most $S_{m} A B s$ depend heavily or entirely on the app store as its primary marketing and distribution mechanism. Firms may also purchase mobile ads from ad networks in hopes to funnel more traffic to the app store and to increase downloads. App stores house app software, handle the download or payment transaction and serve as the app's merchandising storefront. Oftentimes $S_{m} A B s$ engage ad networks to serve mobile ads which, when clicked upon, send consumers to the mobile app store. Ad distribution networks push text, display, video or other types of ads to mobile devices. Depending on the type of pricing structure the $S_{m} A B$ deploys, consumers may or may not be paying customers when they download the app or first register it on their mobile device. After downloading the app, consumers may enjoy a trial period before payment. Figure 2.1.1 illustrates a new business-toconsumer value chain in mobile where the ad network and the app store emerge as key members. The 
mobile ad network creates awareness by disseminating ads to the mobile universe while the app store is the firm's instrument for downloading and payment.

Figure 2.1.1: Main Actors in a B2C Approach to App Selling

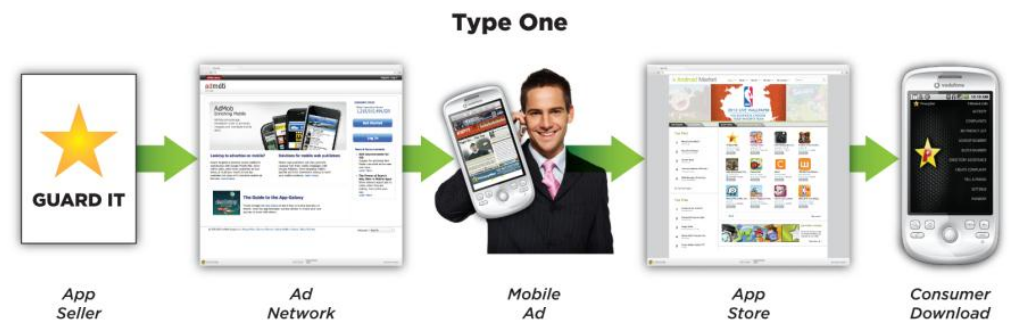

2.2 Mobile Advertising

Firms like the $S_{m} A B$ studied here often experiment with mobile advertising in the hopes of increasing the number of times their app gets downloaded from the app store. Scholars designate this type of digital advertising as push advertising; one-way banner ads running on websites or mobile devices where a large number of consumers are served the same message (Rowley, 2004). Increasingly, firms are raising their annual spend on mobile advertising. Mobile ad expenditures are rising among firms despite the seemingly low click-thru rates (CTRs) compared to average direct mail response rates as reported by the Direct Marketing Association. Online advertising research shows average CTRs for mobile ads are typically below 1 percent per impressions served. MediaMind, an industry research firm, reports a .64 percent average for mobile click-thrus (2011) while JumpTap, an ad network, reports a .52 percent figure. In contrast, the Direct Marketing Association reports an average direct mail response rates across US firms in is 4.4 percent (Schiff, 2012, p.1).

To add to the ambiguity of the effectiveness of mobile ads, scholarly research has recently suggested some types of push advertising may be more or less effective for certain types of mobile products or 
purchases. For example, of the various types of mobile ads, paid-search and location-based, locationbased ads, in which the consumer is served location-specific personalized offers, may be more useful to marketers (Banerjee and Dholakia, 2008). Additionally, push ads may not be as effective as originally predicted in a context where digitally-enabled consumers are simply getting accustomed to "taking the lead within non-linear communication" habits. Scholars suggest these ads may be less effective because they follow a one-to-many, linear scripted flow in which the same communication message is seen by many recipients where the opportunity for feedback is missing (Truncuong and Simmons, 2010). Other scholars have suggested push advertising is hard to generalize about since apps are on a non-level playing field; some forms of push ads may be more effective than others depending on the context of when they are delivered.

\subsection{The Price Conundrum in App Selling}

Aside from uncertainty around the return on investment potential or the share of mobile advertising in their marketing budgets, $S_{m} A B s$ are also challenged with the pricing conundrum in app selling. Information is largely free on the web. The difficulty in creating sustainable business models and competitive advantage in an age of free-flowing information is commonly understood among practitioners and scholars studying strategy challenges such as this one in the digital age. The mobile web landscape is characterized by such flow of "costless information." As Chris Anderson writes, the digital landscape has altered the consumer belief that they should pay for content on the web and that,

If you make a digital product, realize sooner or later it's going to be free - in competitive markets, price always falls to the marginal cost. If you try and ignore this, you're going up against huge forces which are bringing about steady declines...It can't be done. (2009)

To overcome the free expectation by consumers, then, app sellers are utilizing a myriad of pricing approaches to create business models that seek to compensate for such a reversal in how 
products are consumed (See Table 2.3.1). For example, app sellers may opt to give the app away for free to a large number of users only to sell ad space to advertisers or other interested firms who benefit from new end-users. $S_{m} A B s$ may also garner revenue from other firms by selling individual demographic information on its user base which has been collected from inside the app itself. Or sellers may offer free services to end-users in exchange for the user's ability to capture new customers on the seller's behalf. Aside from these strategies, a number of new mobile business models are emerging to address how the firm can garner revenue from its app.

Table 2.3.1: Sampling of Common Pricing Methods used by App Sellers

\begin{tabular}{|c|c|c|}
\hline Name & Value Proposition & $\begin{array}{l}\text { Example } \\
\text { (Category) }\end{array}$ \\
\hline $\begin{array}{l}\text { (Perpetually) } \\
\text { Free }\end{array}$ & $\begin{array}{l}\text { The free model is used commonly when apps already enjoy a large } \\
\text { number of followers or when the app's free trial offer is set to } \\
\text { expire. Free forever apps typically have a large following that } \\
\text { warrants the sale of ad space on their site to other app advertisers. }\end{array}$ & $\begin{array}{l}\text { AngryBirds } \\
\text { DoodleJump } \\
\text { (gaming) }\end{array}$ \\
\hline Freemium & $\begin{array}{l}\text { This term is used to describe revenue model or marketing strategy } \\
\text { used by app sellers to garner revenue from an app that is first } \\
\text { positioned as "free" or partially "free." Firms hope to entice a } \\
\text { broad group of end-users with a "lite" or partial version of the app } \\
\text { with the hope that end-users will purchase more robust versions of } \\
\text { the app after trial. The most common freemium scenarios include } \\
\text { 1) firm offers certain versions of the mobile app as free 2) some } \\
\text { end-users or customers may be paying for the app or supporting the } \\
\text { firm's business model while the bulk of others are enjoying the app } \\
\text { for free or finally 3) certain features (utilities), levels (games) or } \\
\text { editions (news) of the app are "free," but the app seller charges for } \\
\text { other content or upgrades which designated as "Lite" }\end{array}$ & $\begin{array}{l}\text { EverQuest2 } \\
\text { (Social } \\
\text { Games) } \\
\text { Evernote } \\
\text { Flikr \& Flikr } \\
\text { Pro (photo) } \\
\text { India Lite } \\
\text { (News) }\end{array}$ \\
\hline $\begin{array}{l}\text { Pay-Per-App } \\
\text { Download }\end{array}$ & $\begin{array}{l}\text { This revenue model is among the more popular method of paid } \\
\text { mobile apps. After a fixed price is set for the application and } \\
\text { downloads occur, users have full access to all the app's content and } \\
\text { features. An example of the deployment of this model is the CNN } \\
\text { iPhone Application which can be purchased for a one-time fee from } \\
\text { the Apple App Store. Users pay a one-time fee for unlimited access } \\
\text { to news content. }\end{array}$ & $\begin{array}{l}\text { CNN App For } \\
\text { iPhone } \\
\text { (News) }\end{array}$ \\
\hline $\begin{array}{l}\text { Pay-Per- } \\
\text { Issue/Edition } \\
\text { Download }\end{array}$ & $\begin{array}{l}\text { Pay-Per-Edition models simulate a subscription by providing an } \\
\text { expiration date on pay-per-download apps. Consumers are asked to } \\
\text { download and pay for another edition of the app towards the end of } \\
\text { its expiration. For example, users could pay } \$ 12.99 \text { for the } 2012\end{array}$ & $\begin{array}{l}\text { MLB.com at } \\
\text { BAT (Sports) }\end{array}$ \\
\hline
\end{tabular}


In-Application

Subscription

Out-of-

Application

Activation

Out-Of-App

Payment edition of their local newspaper application. On January 1st, 2013, they will be required to download next year's edition if they wish to continue accessing content.

App stores allows publishers to offer applications free to consumers while generating revenue by giving them the option to purchase content though the app store within the application. Users download a free version of the app and then can upgrade by choosing various subscription options from within the app using the iTunes payment mechanism. Slacker Radio, for example, allows free listening to all users, but subscribers forego any advertising interruptions.

Out-of-App activation models allow consumers to purchase an account with a username and password and then return to the app to login. This model allows app developers to bypass Apple's payment system but makes it more cumbersome to purchase, as users must leave the app and return with credentials. Though users are able to download the app for free using this model, they are not able to access any of the content or use any of the apps features without a username and password.

Similar to in-app subscriptions, this model allows consumers to access limited amounts of information and features within an application and purchase additional levels of access thought payment mechanisms outside of the application platform. This model often requires complex development to authenticate users accessing content behind a pay wall. The model may also sync up with web-based pay systems so that paid subscribers can access content on multiple platforms. Several vendors, including Paypal, have been experimenting with these types of mobile payment models. The goal is to provide users with a seamless purchase method that sends them back to the application. Both Apple and Google maintain development restrictions which could cause applications using this model to be rejected.
Slacker

(Music)

Wall Street

Journal-

Mobile Reader

(News)

Touchnote

(utility)

\subsection{The Importance of Customer Acquisition Cost}

Customer acquisition cost is a key measure for app sellers who are measuring the return on mobile ads while attempting to price their products strategically. App sellers, like other direct and digital marketers, use customer acquisition costs or cost of customer acquisition (CoCA) to analyze and compare the performance of various forms of measurable promotion. Customer acquisition costs are increasingly used in several genres of digital marketing including online desktop advertising and 
mobile marketing. The CoCA measure is custom to the firm contingent on the sum of costs management believes are associated with new customer acquisition and with the length of time they believe customers will continue to pay on their Customer Lifetime Value (CLV) measure.

To understand the total costs of capturing and keeping a paying customer, mobile app sellers must understand the entire scope of the end-user "funnel" from start to end (see 2.4.1). If the firm is considering mobile advertising, calculating CoCA scenarios beforehand enables strategists to justify certain forms of advertising as to their ability to deliver enough paying customers to the doorstep. Oftentimes however, firms have difficulty arriving at the CoCA (due to lack of data) or they are not cognizant as to its insight when trying to build a profitable business.

The beginning of the funnel is denoted in Table 2.4.1 below as "The Source" of (mobile) ads. In online advertising, these denote ad networks that disseminate ads based on varying fee structures. Although there are many ways to pay for online ads such as PPF or CPM, firms must understand how many ads must be served (impressions) at what price points to get a single registered, paying user. If firms buy mobile advertising at different rate structures, they must normalize the CoCA to depict what it costs to capture one paying customer. The calculated CoCA number should be lower than the lifetime value number. If the average cost of acquisition is higher than the average customer's lifetime value, the business loses money. The acquisition cost per user are too high to bear. When this scenario occurs, the firm may need to seek other marketing and promotion activities where the expenditure is more justified.

After an individual has downloaded and begun using a trial or free product or service, app sellers are next challenged with how to convert these individuals into paying customers. Many apps offer a free 
trial period towards this goal. Following the trial period, a portion of registrants may decide to pay for the app however the percentage who is historically quite small. In accessing its cost of acquisition, the firms must know its "conversion rate" or the percentage of non-paying users that are willing to pay for the app when prompted for payment. If the app is offered on a monthly payment basis, the firm's total revenue may be projected by understanding the cumulative value of its base of paying customers for the estimated life of a typical customer.

Table 2.4.1: The Online CoCA Funnel

\begin{tabular}{|lcccccccc|}
\hline Source & Ads bought & CTR & Clicks & $\begin{array}{c}\text { Signup } \\
\%\end{array}$ & Users & Cost & CoCA \\
\hline Google & $1 \mathrm{M}$ & $0.50 \%$ & 5,000 & $20 \%$ & 500 & $\$ 5,000.00$ & $\$ 10.00$ \\
\hline Ad.com & $20 \mathrm{M}$ & $0.10 \%$ & 20,000 & $10 \%$ & 1000 & $\$ 20,000.00$ & $\$ 20.00$ \\
\hline
\end{tabular}

\subsection{The App Store Bandwagon}

The app store has been the focus of many academic and industry articles since Apple launched the first store in 2008. Quite simply, perhaps, the app store provides a venue to bring a large number of buyers (consumers) and sellers (developers) together in "new and exciting ways" (Campbell \& Ahmed, 2011). Scholars acknowledge that the app store represents a key shift in distribution; consumers have one-stop access to apps while sellers use the app store's direct billing mechanism for payment (Cortimiglia et al, 2011).

For small app sellers, the app store may be especially attractive. The app seller can have access to a worldwide audience (Henze et al, 2011) regardless of the firm's promotional budget. In short, the app store's user rating/review systems and friend-sharing features may offer developers or small firms the opportunity to enjoy substantial economies of scale in marketing promotion provided the ratings and 
user-generated comments are positive. The app store promises a marketing and distribution advantage for small firms who are already challenged with how to reach a large numbers of potential customers with a modest promotion budget. For a fair commission structure (eg 70/30 split of developers to store revenue), small firms have a high-reach, highly-credible rating system with built--in payment efficiencies. App stores house the end-users' account and credit card info already, making it simple for end-user to acquire new apps with just a few taps of the screen.

Today all major device manufacturers and mobile network operators (MNOs) maintain app stores. Apple's store, the App Store, contains over 500,000 total apps while Android's retail store, The Android Market, houses approximately 140,000. App stores typically take a portion of the revenue only if the seller charges up front for the app. If the app maker offers a free trial period for the consumer who eventually pays later, the seller may or may not be asked to share revenue with the app store at a later date. Sellers may also use the app store's payment mechanism to collect revenue from the end-user who is 'in-app.' For example, gaming apps offer higher levels of play or other add-ons to enhance the game which can be purchased 'in-app' using the app store's payment mechanism.

Given the app store's proficiency at marketing, distribution and reach, most $S_{m} A B$ s regard the app store as an indispensable member of the mobile ecosystem. Some app sellers may even look to the app store as a turn-key solution; one that enables management to forego careful marketing strategy decisions relating to target market, channel structure or pricing. The app store, they assume, is a cheap gateway to a global audience of millions of new users. In the introductory stage, app sellers oftentimes regard acceptance in the app store as a major milestone in the company's legitimacy. Subsequently, depending on the firm's promotional budget, small firms may continue to be highly dependent on the app store to advertise to new prospects and collect revenue from existing ones. 
Despite the app store's efficiencies, being overly dependent on the app store to accomplish the firm's marketing and distribution goals may be problematic as the case study will show. Today's app stores are cluttered, making it difficult for one app to stand out above others in its category. In sum, a marketing strategy that is overly dependent on mobile ad tactics to lead ill-targeted consumers to an already cluttered app store is problematic especially if the firm does not have a watchful eye on customer acquisition costs. To illustrate the difficulty in producing a financially viable business in the face of these internal and external obstacles, we discuss the experience of one firm who launches, reevaluates and re-directs its marketing strategy over a 36-month period. After a series of trial and error adjustments to its target market, distribution structure and pricing approach, the firm, GuardIT*, abandons the app store and mobile advertising and launches its app through resellers instead; wellestablished mobile network operators that enable the firm to reduce its marketing expenditures, lower the cost of customer acquisition and better target a more narrowly defined segment of users. Because the latter strategy enhances firm performance, the case study of GuardIT offers evidence for the Efficiency, Novelty and Complementarities dimensions of an ebusiness model approach as set forth by Amit and Zott (2001). In sum, although the allure to develop apps is strong and the barriers to entry low, building and sustaining profitable business model in a climate of "free apps" and other obstacles is complex. Firms who develop sustainable business models may be those that formulate and execute nonconventional marketing and distribution strategies. (*The firm has been renamed GuardIT for the purposes of this study).

\section{Theoretical Frameworks}

\subsection{Strategic Management Literature}


This research demonstrates the notion that business strategies, whether executed in a traditional or in a purely digital environment, are often the result of iterative, trial and error adjustments by management teams (See Figure 3.1.1). Scholars have previously noted how a firm's intended or deliberate business strategy is oftentimes derailed and then readjusted as a superior one emerges (Mintzberg, 1985). The organization may begin with an understanding of the decision it faces or the route to its solution but only a vague idea of what the solution might be and how the organization will evaluate it when it is developed. It is only by wading through a recursive, discontinuous process, involving many different steps and a host of dynamic factors over a considerable period of time is a choice made (Mintzberg, 1976). The intended or deliberate strategy then oftentimes resembles the realized one very little.

Figure 3.1.1: How Firm Strategy Evolves

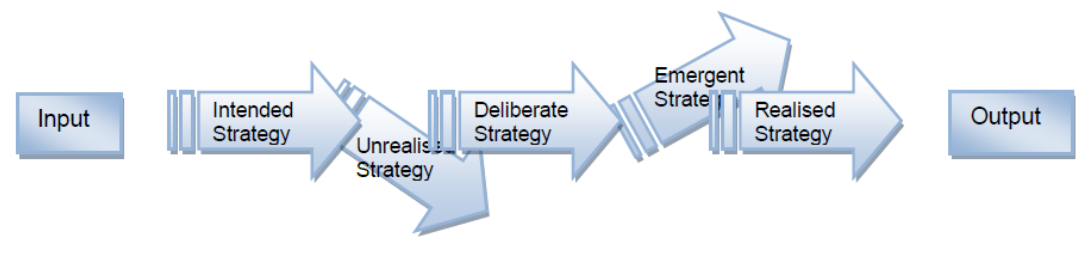

Source: Mintzberg and Waters, 1985

This research also offers further support to the notion that, as scholars have noted, firms need to understand when in the strategic planning process to adapt the business model in order to successfully commercialize a technology (Chesborough \& Rosenblum, 2002). The dynamic nature of the web may further mandate this requirement. Due to rapid change that characterizes newer marketplaces, scholars have noted that firms here are often forced to re-evaluate their business strategies regularly if they hope to successfully commercialize their product (Fahy \& Hooley, 2009). This principle applies to digital entrepreneurships whose management may be reluctant to adapt the business model in the face of necessary change. At the point when principals or founders of a new digital venture have "mastered the technology needed to operate their business," these individuals often feel "that they know what 
they need to need to know in order to be successful and likewise disregard the principles of market orientation" (Esmaeeli, 2011). Accordingly, this mentality is likely to lead to the failure of the venture (Esmaeeli, 2011). These tendencies may highlight the need for thoughtful business model planning whereby the firm's target market, channel organizational structure and pricing approach are regarded as key elements of success.

\subsection{Mobile Technologies Literature}

Since the convergence of mobile and internet technologies, there has been a large body of scholarly literature addressing mobile technologies. Scholars have explored mobile entertainment, mobile financial applications, location-based services and more recently social applications. Others have also contributed to this maturing area of literature by offering frameworks to explain the infrastructure, middleware providers, content providers and other network actors required for the functioning of wireless architectures (Ngai and Gunasekaran, 2007). A wave of academic research in mobile value chains came with the invention of $3 \mathrm{G}$ networks, wherein scholars developed frameworks for understanding the categories of and value contributed by key participants (Meneke and Strader, 2003). See Figure 3.2.1. After the commercial success of the first app stores, literature on value chain ecosystems began to include a discussion of the app store as a major actor in this system. With the growth in the number and types of app stores and the rise of these entities as powerful new players in the mobile value chain, scholars have begun to address the business models and supporting strategies of device manufacturers and OS providers themselves (Muller et al, 2011). In short, the app store requires a business model unto its own for making money. 
Figure 3.2.1: An Earlier Value Chain Framework in Mobile Literature

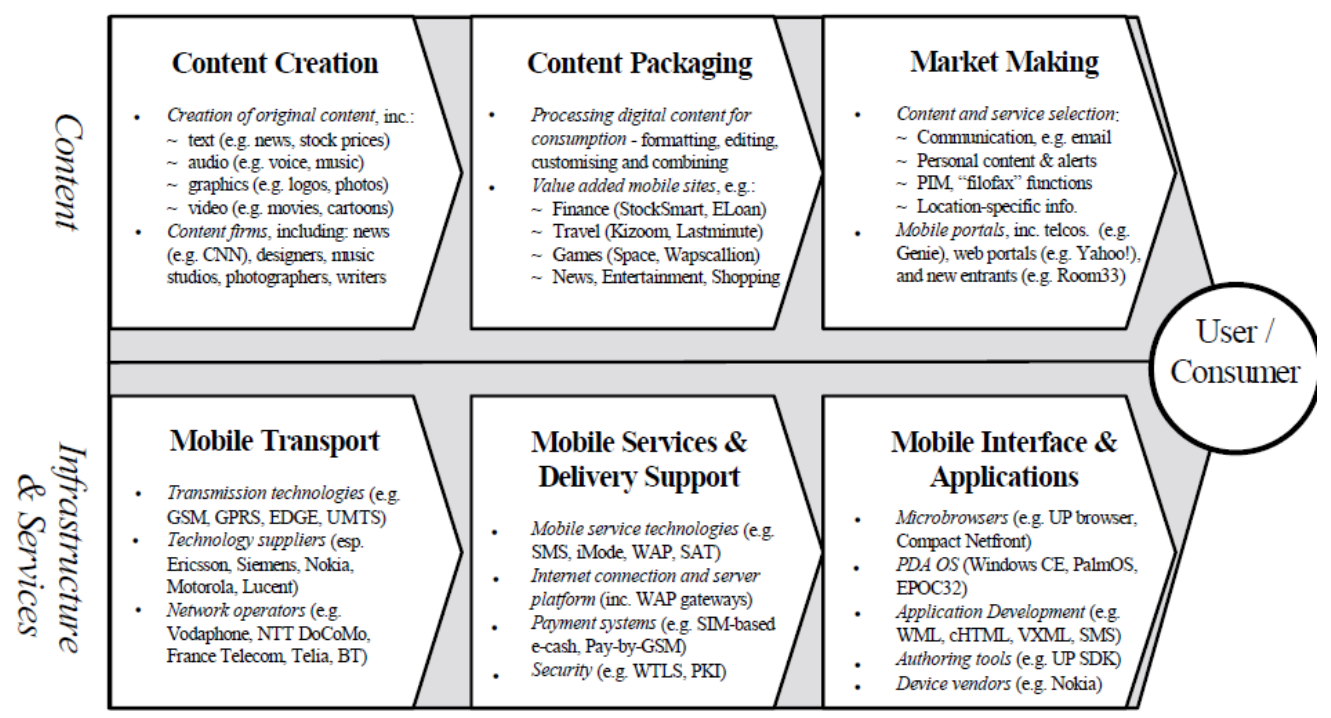

Source: Mennecke and Strader, 2003

Aside from recognizing the app store as distribution platform, scholars have also begun to explore how firms advertise on mobile devices. In the marketing literature, researchers are seeking to build frameworks for mobile advertising (Baeur, 2005), understand consumer willingness to purchase from mobile devices (Kowatsch et al, 2011) and understand consumer acceptance of mobile advertising (Baeur et al, 2005; Hong et al, 2008; Jayawardhena et al, 2009; Truog \& Simmons, 2011). The rising academic interest in mobile advertising parallels the projected increase in mobile advertising budgets by firms in the future (Digital Marketer, 1-12). US mobile ad spending is now expected to reach \$2.61 billion in 2012, an increase of 80 percent over 2011 (eMarketer, 2/12).

\subsection{Business Model Literature}

As mobile research matures, scholars will move from publishing articles on technology to instead looking more closely at how firms in mobile formulate strategies and business models (Ngai \& Gunasekaran, 2005). Here, we will assume the business model is a concept used by marketing and 
management to create strategies for "how the firm will perform" (Leem et al, 2004) or "how the firm makes money" or "how it delivers value to the customer" (Teece, 2010). The term has also been used to describe "the firm's method of doing business by which it can sustain itself, that is generate revenue...by spelling out how the firm makes money relative to where it is positioned in the value chain" (Rappa, 2004). Without an "established theoretical grounding in economist or in business studies" (Teece, 2010), there is neither a general consensus between how bricks and mortar business model concepts differ from those of e-business firms (Leem et al, 2004), although some have noted the right business model is rarely apparent early on in emerging industries (Shirky, 1999). To illustrate the wide range of meanings for business modeling, popular descriptions and themes for understanding the business model concept are found below (see Table 3.3.1).

Table 3.3.1: Selected Business Model Themes in Academic Literature

Author/Source $\quad$ Key Theme(s) of the Business Model
Academic Literature

Timmers (1998)

Osterwalder and Pigneur (2002)

Hedman \& Kalling (2003)

Afuah and Tucci (2003)

Yip (2004)

Leem et al (2004)

Rajala and Westerlund (2007)

Rappa (2004)

Teece (2010)
Firm value proposition, actors, role, customer revenue

Description of value to customer segments, architecture \& networks

for delivering value for sustainable, profitable revenue streams

Customers, competitors, the offering, activities, resources and factor market interactions

The method by which a firm builds and uses its resources to offer its customers better value than its competitors and to make money doing so

Nature of the business, description of how revenues are created

Strategy, revenue generation, partnerships (mobile)

Value proposition, set of actors involved, revenue generation

Revenue, value chain position

Description of how the firm makes profit

Earlier works in the strategy literature look to the firm's business model to describe its blueprint or architecture for delivering products, services and information flows (Timmers, 1998). More recently, scholars agree good business model definitions must outline who the key actors are and what roles they play in generating revenue for the company (Haaker \& Bouwman, 2006; Kallio et al, 2006). 


\subsection{Ebusiness Model Literature}

Somewhat dissatisfied at the capability of a single theory in strategic management to explain the ways value is created in e-business models, Amit and Zott (2001) contribute a new theory of strategic management with roots in:

1) Schumpeterian innovation. This body of literature uses innovation as the source of value creation in business models. Creative destruction says following disruptive change, 'rents' become available to first movers but expire when they become available to all (Schumpeter, 1934).

2) Strategic Network Theory. These networks are stable inter-organizational links which take the form of alliances, joint ventures and other types of partnerships to bring new types of value to digital and non-digital firms (Gulati, 2000, Dyer \& Singh, 1998) by

3) Transaction Cost Economics. Build or buy decisions should be a function of transaction efficiency; firms that economize on transaction costs can extract more value from transactions (Williamson, 1975).

4) Resource Based View. Firm marshals and combines complementary and specialized resources and capabilities to create value. Later dynamic capabilities are rooted in managerial and organizational processes such as product development and collaborative alliances (Barney, 1991).

5) Value Chain Analysis. Beginning with Porter, this stream of literature identified the activities of the firm and studies economic implications of those activities to learn what of these activities enable it to add value to the product. Activities are logistics, operations, marketing/sales, customer service. Firms enjoy competitive advantage by differentiation of one or all of these activities (Porter, 1985). 
Figure 3.4.1: Value Drivers in eBusinessModels

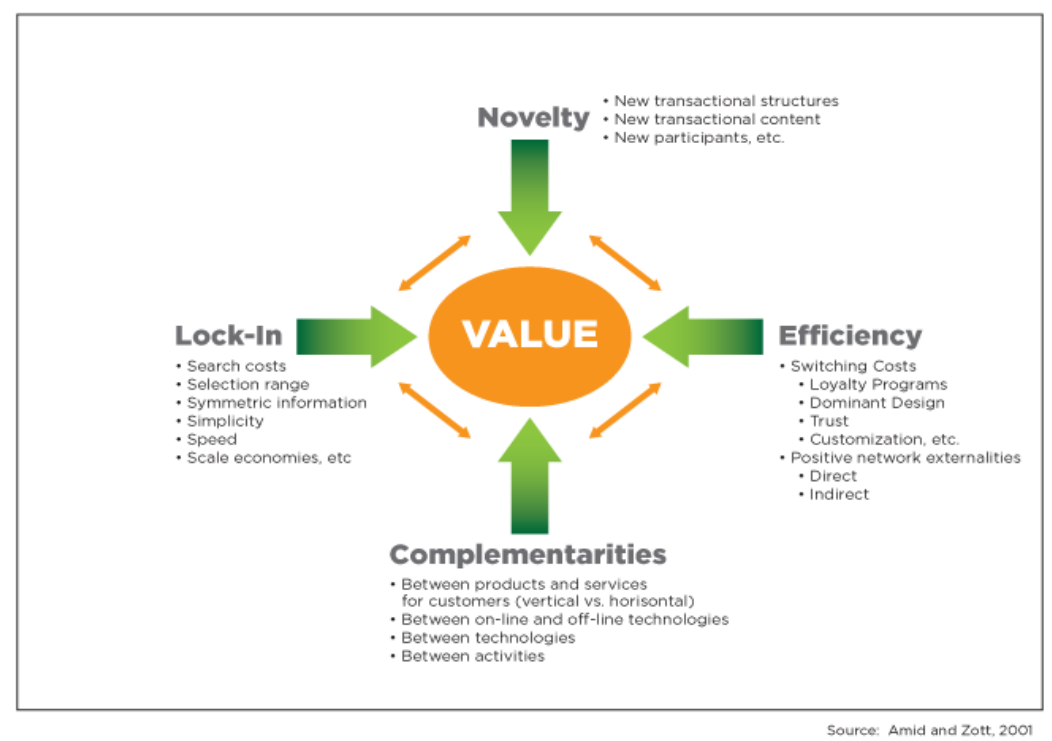

This study will draw heavily on Amit and Zott's model to confirm three of four of the authors' value dimensions.

\section{Method}

This study uses the case study of one firm to illuminate the marketing strategy issues facing $S_{m} A B s$ as they attempt to develop financially performing business models among a myriad of internal and external obstacles. The case documents the experience of one firm who implements two distinctly different business models in succession over a 36-month period. The firm chosen to study this problem is exemplary of many small, self-funded, digital entrepreneurships seeking to develop and market mobile smartphone apps for a profit.

The research team conducted over 110 in-person and telephone interviews, participated in multiple email exchanges and analyzed both primary and secondary data over a 24-month period (See Table 4.1). Over this 24-month period, the research team studied the firm's business activities spanning 36- 
months. Oral interviews were conducted with the company founders/executives and mid-level management, but subordinates were also consulted to understand business processes such as marketing campaign execution and end-user licensing. The researcher also interviewed ad network vendors in hopes of understanding the typical practices of how mobile advertising is priced and measured.

Table 4.1: Summary of Research Activities

\begin{tabular}{|c|c|}
\hline Documents \& Artifacts & In-depth, Semi-structured Interviews \\
\hline $\begin{array}{l}\text { Quarterly company } \\
\text { financial statements from } \\
\text { Q4 } 2008-\text { Q1 } 2012\end{array}$ & $\begin{array}{l}110+\text { hours of interviews with key informants and market experts including } \\
\text { GuardIT executives, customer service reps, marketing agency personnel and } \\
\text { ad network vendor representatives }\end{array}$ \\
\hline $\begin{array}{l}\text { Company operational } \\
\text { documents including work } \\
\text { process flow charts, } \\
\text { customer billing } \\
\text { statements }\end{array}$ & $\begin{array}{l}>300 \text { email exchanges with senior management and other company } \\
\text { employees } \\
\text { Organizational Titles of Informants: } \\
\text { Chief Founder }\end{array}$ \\
\hline $\begin{array}{l}\text { Industry research reports } \\
\text { on mobile marketing }\end{array}$ & $\begin{array}{l}\text { Founder } 2 \\
\text { Founder } 3 \text { (Acting President) } \\
\text { Marketing Manager }\end{array}$ \\
\hline $\begin{array}{l}\text { Marketing documents } \\
\text { including ad campaign } \\
\text { creative samples and } \\
\text { reports, customer surveys } \\
\text { and comments reports }\end{array}$ & $\begin{array}{l}\text { Operations Manager } \\
\text { Customer Service Manager }\end{array}$ \\
\hline
\end{tabular}




\section{Case Study}

\subsection{Company Background}

The firm under study, GuardIT, is a small entrepreneurial venture founded in 2008 to develop, market and support a mobile-only privacy app for Android and Blackberry handsets. The initial a utility app from GuardIT was designed to perform two major functions 1) guard consumer privacy by blocking calls and 2) identify unknown mobile callers uniquely by name. The company was founded by a consortium of private investors who had previously been successful in the deployment of marketing technologies for the direct marketing industry. Prior to the GuardIT venture, these investors founded, led and grew a technology firm successfully over three decades. Founded in 1969, the firm went public in 1983 and grew into a $\$ 1$ billion corporation by 2005. In 2008, the Chief Executive/Founder, a Senior Executive Vice President and senior member of the financial team exited the corporation and founded GuardIT. These executives continue to lead the strategy development of GuardIT today and are highly involved in day-to-day decision-making.

The founders of GuardIT initially funded operations with private capital. A substantial amount of capital was used in 2008 to purchase data from one large data aggregator. This data would enable GuardIT to build a data repository housing mobile data subscribers and their identities. The app would access the intelligence of this knowledgebase to perform the caller id feature on the end-user's smartphone. With a lifetime of successful technology careers and 80 years combined experience in the marketing database industry, the founders of GuardIT were well-versed in how to acquire US consumer data and transform it into commercially-viable products. 
Despite decades of commercial success in their prior careers, however, the founders of GuardIT faced initial hurdles in devising and executing a business strategy that would show any promise towards positive financial results. Figure 5.1.1 depicts a three-phased timeline which helpful in segregating the firm's stages of strategy formulation and implementation discussed in this case.

Figure 5.1.1: Timeline of Events

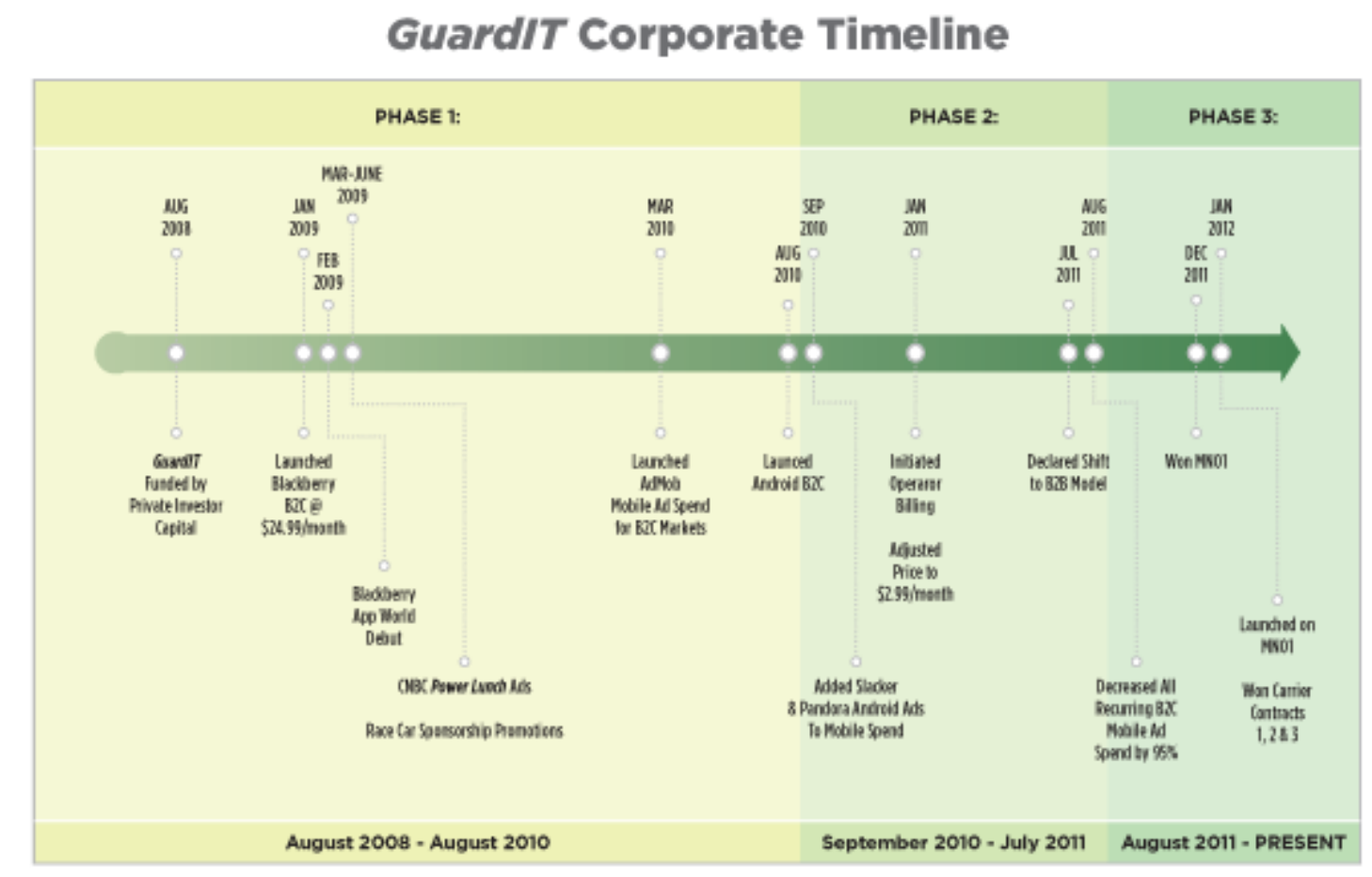

\subsection{Phase I}

At launch and during Phase I, the founders of GuardIT believed the "Blackberry-carrying executive" was the segment best-suited for its app. To acquire these customers in sufficient numbers, GuardIT, assumed friend recommendations, regular mobile advertising and good ratings in the app store would produce enough paying customers to fund operations and make the business profitable within one year. The founders of GuardIT were especially enthusiastic at the possibility of offering busy executives an 
app that would identify mobile callers by name. Identifying mobile callers by name was a feature the founders personally valued deeply; a feature they believed so disruptive that end-users would pay more than 20 dollars for each month. The chief founder of GuardIT believed earnestly, without evidence from prior marketing research on consumer price points for apps, that executives would easily pay $\$ 24.99$ each month for an app that enabled them to see the named identity of mobile callers. Following the chief founder's lead, all founders were confident that the $\$ 24.99$ price point was palatable given the fact that no competitive app or mobile identification service was available on the market. The founders believed that the high monthly price was justified by the disruptive nature of the app and by large number of add-ons under development. For example, aside from its privacy features, the app includes the ability for consumers to automatically file FTC complaints against telemarketers. (See Figure 5.2.1 for a complete feature set).

Figure 5.2.1. GuardIT Full Feature Set Phase I

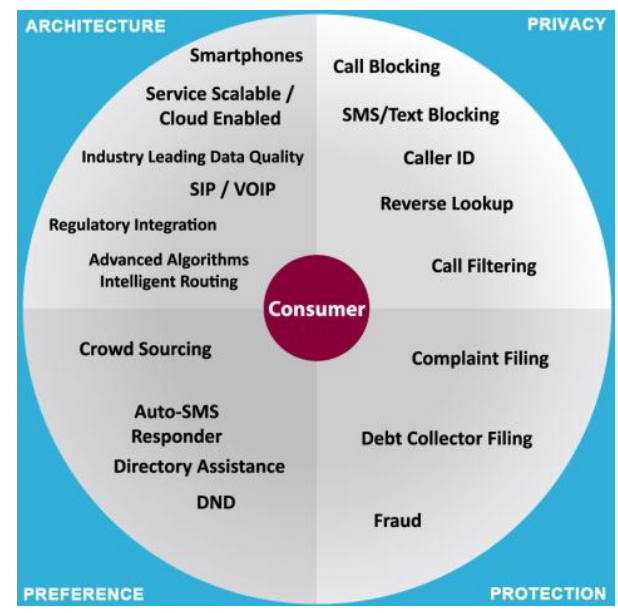

To create an on-going revenue stream for GuardIT, the founders initially envisioned a subscriptionbased pricing approach. The firm expected it would need on on-going revenue stream to service the 
ongoing costs for mobile data, research and development, and maintenance costs required to update the software regularly. Additionally, during the first few months, GuardIT invested heavily in organizing the people and business processes that would enable each paying customer to hold a license for the app software. Licenses would enable the firm to track holders of the app and offer them updates easily as they were made available. All mobile apps do not include individual user licenses. Although not critical to operations, the founders also invested heavily up-front in customer service personnel to provide technical assistance via phone or email.

Although the earliest version of the GuardIT app was released for Blackberry devices only, the founders intended in the future years to offer the GuardIT app on at least one model of all major operating systems including Android, Blackberry, Symbian, IOS, and Windows. Thirty-six months later, the GuardIT app works on hundreds of types of Android and Blackberry models.

Target Marketing, Channel Choice and Pricing Approaches in Phase I

In the spring of 2009, GuardIT briefly deployed several mass marketing promotional campaigns such as commercial spots on cable networks such as MSNBC. The primary marketing goals for this spend were to introduce the brand and create awareness among the firm's intended target market: a narrow segment of privacy-conscious business people in the US whom management assumed were fairly insensitive to price. Management assumed this segment of consumers belonged to a higher socioeconomic demographic group of innovators and early-adopter types; executives who were technology savvy and intrigued by "new gadgets." The founders believed that once this segment was educated as to the exclusivity nature of the app, they would visit the app store, download the trial and pay the monthly subscription of $\$ 24.99$ to continue it. GuardIT assumed these individuals would be 
well-suited for the app because they would welcome novel ways to identify unknown callers. The founders conducted no market research such as focus groups or surveys to confirm these suppositions, nor did they confirm the initial price of the app should be set at $\$ 24.99$.

During Phase I, Blackberry App World was the only distribution platform for GuardIT. In 2009, the founders were enthusiastic at the potentially high marketing exposure to come from the app store's rating and review system since there were no competing apps in its category. Being a novelty app in the app store gave GuardIT an image of having a progressive, exclusive product; one which aligned with its target market's motivations. Management believed the app store was a more progressive way to download the app than tethering the mobile device to a desktop computer via a USB cord which could also feasibly work for downloading. Executives did not consider any other distribution channel alternatives but instead believed Blackberry App World was a congruent channel to reach tech-savvy business professionals and early adopters looking for smartphone novelties.

As a small business, GuardIT was also initially drawn to Blackberry App World's rating system as an attractive marketing resource. Without charging any fee, App World features popular apps on the site's landing page and offers ratings and reviews by end-users by categories. Because there is no fee to app sellers for this service, the firm believed the app store was a formidable marketing resource not just for distributing the app but for giving GuardIT a way to advertise to prospects at no cost. As a result, the app store was the sole method by which consumers could download GuardIT to their device. Casual browsers in the app store might run across GuardIT when looking for a particular category of privacy utility or prospects might be directed to the app store after they clicked on mobile ads sent to their device. 
GuardIT was featured in the Blackberry app store, App World, four times from the period February 2009 to September 2011. According to the president, the first feature was the most effective one.

When we launched GuardIT for Blackberry, there were only four thousand total apps in App World and no other utility apps of our kind existed there. Soon after we got approval in Blackberry World, they offered to feature us on the landing page. For the two days we were featured, we received about 300 registrations per hour. The results were phenomenal. But contrast this with the experience we had in the summer of 2011 (Phase II). We were featured in another app store, one housing over 100,000 apps, and the activity was weak. We only got about 40 registrations per hour... and fewer of these folks converted. App stores are just cluttered now and now there is much more competition in our category. Blackberry has more than 100,000 apps. And today, there are about 11 other apps who compete directly with us.

Mobile Ad Campaigns

Aside from the app store's free promotion, GuardIT looked to paid mobile advertising to acquire new customers. The firm also initiated bi-weekly spots on CNBC's Power Lunch for sixty days but eventually abandon this effort due to the high costs. At this time, the founders believed strongly also in word of mouth advertising; once the professional Blackberry-carrying community learned of the app, they assumed this group would visit the app store in large numbers to download it. This mentality is perhaps characteristic of the "if I build it, they will come" mindset.

GuardIT also began spending heavily in mobile advertising in Phase I. During Phase I, ad expenditures ranged from a few hundred dollars a day in the early months, Blackberry only in March 2009, to six-thousand dollars a day in April 2011, after the Android version had been added. The founders were convinced that mobile ads would bring an adequate number of trial users and eventually paying customers to their doorstep. At the onset of this expenditure and for several months thereafter, the management team was unclear as to the mathematical relationship between ad impressions served, 
app downloads/registrations received and new customer subscriptions. Generally speaking, the company knew mobile advertising was producing downloads and registration as seen by the relative increase in registrations each time the ad spend increased. However, executives had not yet mastered the CoCA equation in part because the reporting toolsets were not yet being provided by the ad network or OS vendor. It was not until early in 2010, that Google AdMob began offering sophisticated reporting capability for devices running its Operating System (Android). The firm's mobile ad spend for registrations using Blackberry devices however were never directly traceable to registrations. (See Exhibit 2 for a mobile ad sample).

The fact that GuardIT managers had no hands-on history understanding conversion and renewal rates made it more difficult to analyze the return from its mobile advertising investment. After an end-user downloaded the trial version and subscribed for one month, it was unclear how likely the customer was to renew the following month. The inability of mobile ads to produce enough long-term customers became clear to the management only after a period of trial and error over several months of experimenting (see Phase II discussion).

Pricing Missteps

At launch in early 2009, GuardIT originally priced the utility at a fee of $\$ 24.99$ per month. The fee was payable monthly only by credit card. Management believed this segment was comprised of creditcarrying consumers who would prefer to pay by credit card. Prospects downloading the trial version were given a 30-day free usage period and then asked via email or text message if they would like to renew. Finally, after a series of email surveys to end-users who had downloaded and registered the product but not yet paid, the company determined its high monthly fee was a main reason customers 
did not subscribe. In hopes of addressing this issue, GuardIT lowered the monthly price to $\$ 12.99$ in December of 2009. To pay after trial, customers entered their credit card number directly into their mobile device.

Investments in Operations

During Phase I, the company hired 20 people in total and made significant investments in internal processes. These process investments create an operational environment that supports the recruiting and licensing of new customers (See Figure 5.2.2). Management believed that by offering each enduser an individual license to the app, the end-user would deem the product more valuable and be more likely to renew month after month. The founders also believed that by hiring customer-facing employees to solicit messages and handle other duties, such as technical support and post-trial follow up, the firm would be able to establish one-on-one relationships with customers.

As the figure shows, end-users register the product when they download it to their device but are not 'converted' to customer status until they pay. To better conversion rates after registration, the company initiates a series of marketing communication steps developed from best practices marketing guidelines (Mobile Marketing Association). These marketing reminders include email messages, text reminder and nag screen reminders. Nag screens are graphically-designed pop-up announcements asking the user to pay. 
Figure 5.2.2: $\quad$ Internal \& External Support Activities

\section{Customer Acquisition Process}

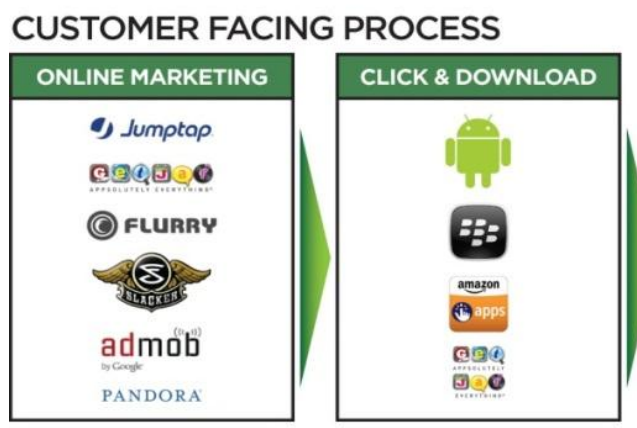

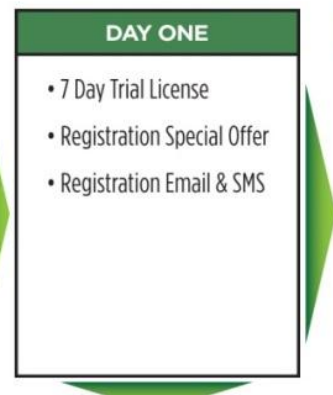
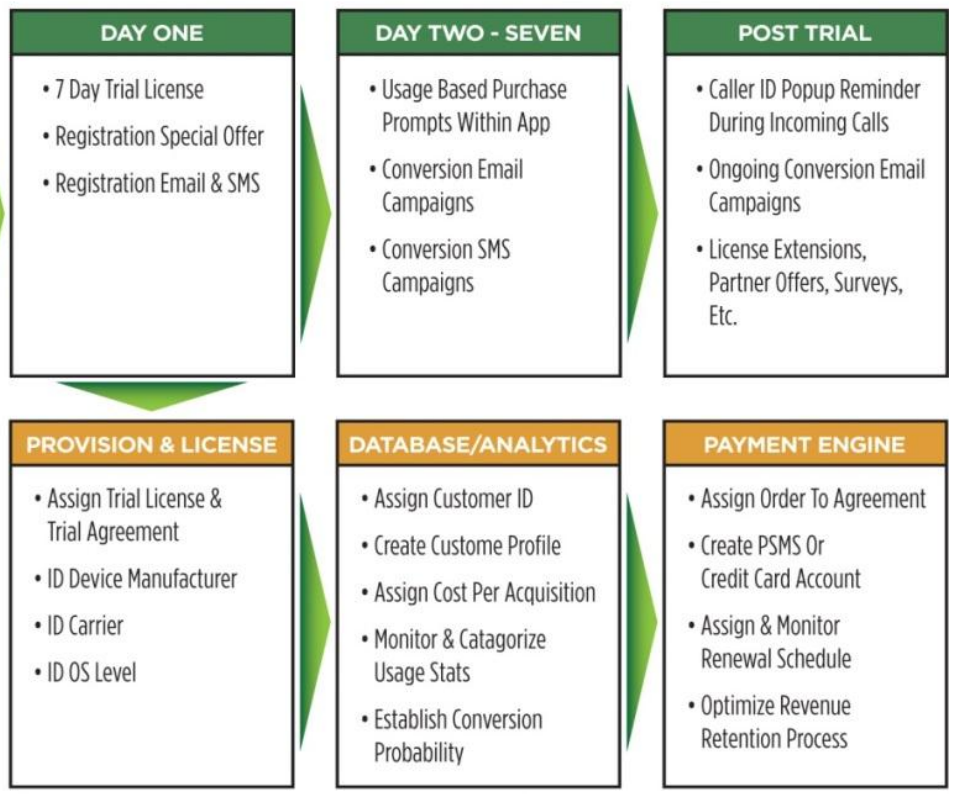

INTERNAL COMPANY PROCESS

\section{PAYMENT ENGINE}

- Assign Order To Agreement

- Create PSMS Or

Credit Card Account

- Assign \& Monitor

Renewal Schedule

- Optimize Revenue

Retention Process

\subsection{Phase II}

In the fall of 2010, shortly after its release of the first Android version of its app, GuardIT began implementing several major adjustments to its business model in hopes of 1) increasing the number of daily downloads and registrations; 2) increasing the rate of customer conversion occurring after the registrant's free trial expires; and 3) increasing its customer retention rate. Although management could not trace a mobile ad click directly to an individual customer yet, they determined that less than 10 percent of end-users downloading the app in aggregate were moving from trial to paying customer status. This disappointing figure, backed by the low click-thru rate on mobile ads, caused the President of GuardIT to question the results the company was getting from a customer acquisition strategy so tied to mobile advertising. Towards this end, GuardIT made several marketing 
adjustments, including experimenting with audio ads, changing the price structure and changing the mechanism by which end-users could pay for the service each month.

Audio Ads

To increase the number of downloads or new registrations from mobile advertising, GuardIT supplemented display advertising with audio (voice) advertising spots on two major app radio channels, Pandora and Slacker. These are radio apps that allow users to customize the genre of music that is played through their smartphone. Users who do not pay for the radio app hear advertisements.

For GuardIT, radio channels were attractive because they offered a performance-based (PPF) advertising model by charging only for downloads and not for impressions (heard). Management was also attracted to mobile radio as a promotion media because the radio channels could deliver audible messages. Since the app was a disruptive mobile utility, they felt audio ads could better explain the service with audio 'instructions' as to its value. At this time, app radio networks also offered their advertisers slightly superior demographic targeting and reporting capabilities; management received a set of custom reports which tied ads directly to new registrations. GuardIT believed mobile radio listeners were the same target who would appreciate GuardIT's app: that is people who listened to mobile radio were also early adopters and looking to their mobile device for new types of enjoyment and utility. At this point, no thought was given by management to the idea that other segments, such as those who might value the call blocking feature, might be better targets for GuardIT.

We like (mobile) radio these days a lot more than non-radio ads because these guys will tell us more about who their listeners are. We also have more faith in the integrity of where they are running the ads. We found out for example our other ad network was running ads inside Angry 
Birds. They were running ads which gave the player points for clicking on our ad. We were charged for the click but got no leads of people really interested in our product. Our radio guys will also do all the creative at no charge, turn it around and give us a daily report on each campaign's performance. Since we are not buying a huge dollar amount of ads, the custom reporting they are giving us is a big plus. The big ad networks will only offer sophisticated reporting to advertisers spending lots and lots of money with them.

\section{Marketing Manager, GuardIT}

After running four major types of audio ad campaigns during Phase II, however, GuardIT determined audio ads for either the Blackberry or Android version did not produce a significantly higher number of total registrations than did non-audio purchased from the mobile ad network. Click-thru rates for three of the four campaigns hovered around the industry norm; below one percent. The click-thru rate for audio ads was similar to the click-thru rate GuardIT was experiencing for mobile display ads on regular mobile sites. The best performing daily radio campaign (Blackberry call blocking) received a .87 percent click thru rate from serving 50,039 impressions with 435 clicks (see Table 5.2.3). Using the company's average retention rate from its historical information on performance, it could be projected that only 38 individuals would purchase and still be paying customers by the end of the second month of service. If audio ads produced 38 customers even at the higher price point of \$24.99 per month, GuardIT would add less than $\$ 30,000$ per month to the top line at a cost of $\$ 8,700$ to acquire them in aggregate. In essence, the high mobile ad investment would not produce enough customers to contribute to the current operating costs of the business.

Table 5.2.3: Audio Ad Campaign Results

\begin{tabular}{|l|l|l|l|}
\hline Device & \multicolumn{2}{|l|}{ Feature highlighted } & $\begin{array}{l}\text { Highest Performing Daily } \\
\text { Campaign }\end{array}$ \\
\hline Blackberry & Call blocking & Caller id & $.87 \%$ CTR \\
\hline Android & Call blocking & Caller id & $.77 \%$ CTR \\
\hline
\end{tabular}

Pricing Adjustments and Revised Billing

In hopes of acquiring paying customers more quickly, GuardIT also shortened the app's trial period during Phase II. Email surveys showed trial users and existing customers would be just as likely to 
purchase if there were fewer days in the trial period. As a result, GuardIT shortened the trial period from 30 to 7 days to all new downloading registrants in hopes of quicker conversions. Survey feedback also suggested customers might prefer other payment options such as annual billing or paying for the service through their mobile telecommunication carrier as a 'premium service' line item.

In response to this feedback, GuardIT lowered its monthly price to $\$ 2.99$ and offered an annual payment option with a discount. Management also instigated and implemented carrier billing with four major telecommunications carriers: AT\&T, T-mobile, Sprint and Verizon. GuardIT believed by letting customers pay through their carrier as part of a premium package, customers would be more likely to stay each month. The general consensus among the management team was that by asking customers to key 16-digit credit card numbers into their small device, they were creating a bottleneck in payment. This inconvenience would keep trial users from moving to paying customers, and it could also be hindering existing customers from renewing. In the revised billing arrangement where carriers would handle billing, existing customers who had agreed to a year of service could simply add GuardIT to their monthly bill as a line item entitled 'premium services.' To begin carrier billing, endusers would have to respond to a text message to begin the cycle. While this tactic may have served to lower attrition or churn rates slightly, it did not offer as significant a lift as was originally expected; customer retention rates rose only slightly after the change.

The failure of carrier billing to decrease churn may be due in part to a best practices policy of telecommunications carriers. This policy force customers to re-confirm via text or other methods that they would like to continue service with the premium (outside) vendor. For example, although a consumer may have agreed to an annual commitment for GuardIT services, T-mobile still asks subscribers each month to re-approve the charge. This behavior is representative of the tendency for established players like carriers to erect 'walled-garden portals' wherein they are in control of the 
customer relationship. In short, although the consumer has committed to annual agreement, if he does not re-confirm to T-mobile each month the GuardIT service is dropped or discontinued. GuardIT managers determined this 'best practices' behavior confused some of their customers who feared being double-billed. In all, then, carrier billing did not have the desired effect on the overall conversion or retention rates.

Lackluster Financial Results

At the end of this period of adjustments, the company determined these fixes were still not sufficient to support a financially viable business model. Net losses climbed to $\$ 1.6$ million for the 6-month period ending June 2011. These losses were incurred after a cumulative spend on mobile advertising totaling $\$ 959,482$.

Figure 5.2.4: Unaudited Income Statement, January - June 2011

Cash Basis

\begin{tabular}{|c|c|c|c|c|c|c|c|}
\hline \multicolumn{8}{|c|}{$\begin{array}{l}\text { Profit \& Loss - Unaudited } \\
\text { January through June } 2011\end{array}$} \\
\hline & Jan 11 & Feb 11 & $\operatorname{Mar} 11$ & Apr 11 & May 11 & Jun 11 & TOTAL \\
\hline \multirow{2}{*}{\multicolumn{8}{|c|}{ Ordinary Income/Expense }} \\
\hline Income & & & & & & & \\
\hline Revenue-Carrier Billing & 19.435 .00 & $28,106.00$ & $36,750,09$ & $47,840.00$ & $49,083.84$ & $49,027,03$ & $230,241.96$ \\
\hline Revenue-Carrier Billing Comm & $(7,735.00)$ & $(11,186.00)$ & $(14,626.29)$ & $(19,040.00)$ & $(19,535.04)$ & $(19,512,43)$ & $(91,634.76)$ \\
\hline Revenue-Credit Card & $16,945.03$ & $20,713.17$ & $19,970.99$ & $31,282.41$ & $27,139.57$ & $19,983.36$ & $136,034.53$ \\
\hline Total Income & $28,645.03$ & $37,633.17$ & $\frac{42,094.79}{4}$ & $60,082.41$ & $56,688.37$ & $49,497.96$ & $274,641.73$ \\
\hline Gross Profit & $28,645.03$ & $37,633.17$ & $42,094.79$ & $60,082.41$ & $56,688.37$ & $49,497,96$ & $274,641.73$ \\
\hline \multicolumn{8}{|l|}{ Expense } \\
\hline Advertising \& Marketing & $154,870.05$ & 83.679 .52 & $210,845.72$ & $188,813.00$ & $144,997.50$ & $196,276.43$ & $959,482,22$ \\
\hline Data Center/Computer Related & $11,672.20$ & $14,158.80$ & $14,405.89$ & $1,904.61$ & $27,598.82$ & $15,035.72$ & $84,776.04$ \\
\hline Data Purchases & $2,246.97$ & $2,092.86$ & $2,097.06$ & $1,851.70$ & $9,262.72$ & $2,112.98$ & $19,664.28$ \\
\hline Other Expenses & $23,520.64$ & $14,642.76$ & $13,392.82$ & $14,733.35$ & $29,568.34$ & $18,210.69$ & $114,068.60$ \\
\hline Payroll \& Benefits & $105,630.78$ & $103,018.26$ & $106,086.35$ & $98,575.62$ & $104,661.68$ & $107,948.25$ & $625,920.94$ \\
\hline Professional Fees & $3,000,00$ & $23,016.41$ & $2,500.00$ & $4,490.00$ & $9,575.00$ & $21,684.50$ & $64,265.91$ \\
\hline Software Development & $35,495.00$ & $30,082.64$ & $28,191.58$ & 18.427 .21 & $24,534.87$ & $34,710.31$ & $171,441.61$ \\
\hline Temporary Labor & 0.00 & 0.00 & 0.00 & $1,035.72$ & $4,385.37$ & $4,545.66$ & $9,966.75$ \\
\hline Travol \& Ent Costs & $1,278.12$ & 4.780 .55 & $7,020.56$ & $5,208.43$ & $7,948.73$ & $5,170.65$ & $32,407.04$ \\
\hline Total Expense & $337,713,76$ & $275,471.80$ & $384,539.98$ & $316,039.64$ & $362,533.03$ & $405,695.19$ & $2,081,993,40$ \\
\hline Net Ordinary Income & $(309,068.73)$ & $(237,838.63)$ & $(342,445.19)$ & $(255,957.23)$ & $(305,844.66)$ & $(356,197.23)$ & $(1,807,351.67)$ \\
\hline \multicolumn{8}{|l|}{ Other Income/Expense } \\
\hline Other Income & & & & & & & \\
\hline Sale of AR Tax Credits & 0.00 & 0.00 & 0.00 & $151,258.50$ & 0.00 & 0.00 & $151,258.50$ \\
\hline Total Other Income & 0.00 & 0.00 & 0.00 & $151,258.50$ & 0.00 & 0.00 & 151.258 .50 \\
\hline Net Other Income & 0.00 & 0.00 & 0.00 & $151,258.50$ & 0.00 & 0.00 & $151,258.50$ \\
\hline Income & (309,068.73) & $(237,838.63)$ & $(342,445.19)$ & $(104,698.73)$ & $(305,844.66)$ & $(356,197.23)$ & $(1,656,093.17)$ \\
\hline
\end{tabular}


During a telephone interview conducted in February of 2011, the president offered these remarks in retrospect as to why the firm began searching for an alternative business model at that time. In short, he admitted executives were not as sensitive as they could have been to customer acquisition cost. If conducted, a thorough customer acquisition cost analysis would have revealed earlier that mobile ads were too costly and were adding new customers at too slow a pace to produce a financially viable business.

Don't get me wrong...I'm not saying mobile ads don't work. I'm saying we just didn't have the millions to spend on them to acquire customers one by one. Customer acquisition costs are just too high going direct to the market. More competitors are coming on line too...we are not the only game in town anymore so we had to find another way to scale the app or we just would have run out of cash.

\subsection{Phase III}

After implementing targeting and pricing adjustments as described above, executives at GuardIT were still faced with lackluster financial results for the current period and less-than-promising proforma projections for the months ahead. In short, although mobile ads were able to draw end-users to the app store, the slow pace and overall cost of customer acquisition was proving too costly. Due to poor results and weak projections for the future, then management determined the company should abandon its existing marketing strategy entirely in July of 2011. To grow using the old approach would require the company to be wholly dependent on the higher click-thru and higher conversion rates after the trial period. Barring a viral campaign or another type of word of mouth initiative, the company believed it could not grow to a substantial size by single transactions. To grow by mobile advertising would require a mobile spend in the millions of dollars; capital the founders were not willing to commit. The abandonment of this approach was reflected in a 95 percent reduction in mobile ad spend by August of 2011. As an Operations Manager noted: 
We finally just agreed to pull the plug totally on mobile advertising. I guess we could have gotten to a profitable business by using mobile ads but it might have taken 10 years to get there... besides by being forced to go another route, we figured out the executive segment wasn't really the best target market for our app anyway.

Upon realizing the substantial investment required for mobile advertising and upon realizing that professionals may not be as keen on the caller id feature as management once believed, GuardIT began to consider who was really using the product, how they were using it (ie which features produced which benefits) and what channels might best connect the company to viable prospects.

To better understand the apps' favorite features, GuardIT conducted an email survey to existing users. The survey revealed the app's most popular feature among its active customer base was the app's ability to block unwanted calls from debt collectors. This feature emerged clearly as the main benefit sought by the group of active customers surveyed. This finding was enlightening to the founders: the users of GuardIT were not professional executive types interested in identity after all. The realization of what loyal customers were actually buying caused GuardIT to consider targeting a group of creditconscious consumers who may be looking to the app to prevent bill collectors from calling their mobile phone. With this realization, the challenge management now faced was how to market to this large group of consumers at a price point the segment would accept.

Armed with a new understanding of what users of the product wanted and underwhelmed by the performance of mobile ads and the ability of the app stores to promote their app, management considered for the first time an alternative distribution method. During this period, the founders of GuardIT also decided to scale-down the app feature set to only include the blocking feature. The caller id feature, for example, was dropped since this feature was expensive to maintain but not highly valued by users. 
The Reseller Opportunity

Because the founders of GuardIT had grown a previous start-up company to greater than one billion in annual revenue by forging business-to-business relationships with large retail and financial services firms, the notion of approaching large corporations to potentially serve as GuardIT resellers was not intimidating to the founders. GuardIT considered carriers and mobile network operators (MNOs) who offered high reach to credit-conscious consumers. Mobile Network Operators, such as Metro PCS and Cricket, for example, typically service cash-only customers who tend to pay their bill each month inperson at the retail store. GuardIT executives set out to forge relationships with a wide range of compatible regional networks and mobile network operators including Metro PCS, Cricket, Alltel, NTelos, GCI, and Flat Wireless. Management believed MNOs offered walk-in access to the very type of cash-carrying customers who would derive immense benefits from a blocking app. Sales visits by the founders to several MNO corporate offices in the fall of 2011 revealed MNOs would be very interested in the call-blocking utility since many of their competitors did not offer the feature at all or only offered this feature at a network and not a device level.

Product Positioning Adjustments: Scaling Down the App for a New Demographic

Since MNO subscribers would be primarily interested in the blocking functionality of the app, GuardIT devised, tested and released a scaled-down version of the app for Android and Blackberry devices that only blocks calls. This version of the app would first be offered as reseller agreement to MNOs meaning that the MNO would offer the blocking feature alongside other 'preferred' apps in their bundle for a fee of $\$ 1.00$ each month. GuardIT would retain 40 cents on each transaction. While this revenue-share appeared unbalanced at first, the founders agreed these margins were reasonable given they no longer had large data acquisition costs associated with the full-featured version of the 
app. Additionally, GuardIT expected to enjoy the benefits of having the MNO disseminate text and email promotions on their behalf at no additional fee. The 'perks' of having the MNO initiate marketing campaigns on their behalf would offer huge economies of scale in marketing promotion dollars. Finally, GuardIT believed having the MNOs sales staff on-hand to educate the target market on the floor, downloading and explaining the app would be a strategic advantage; no apps developed by competitors were being sold on the retail store floor. Figure 5.3.1 outlines the reseller or B2B2C arrangement.

Figure 5.3.1: B2B2C Distribution in Phase III

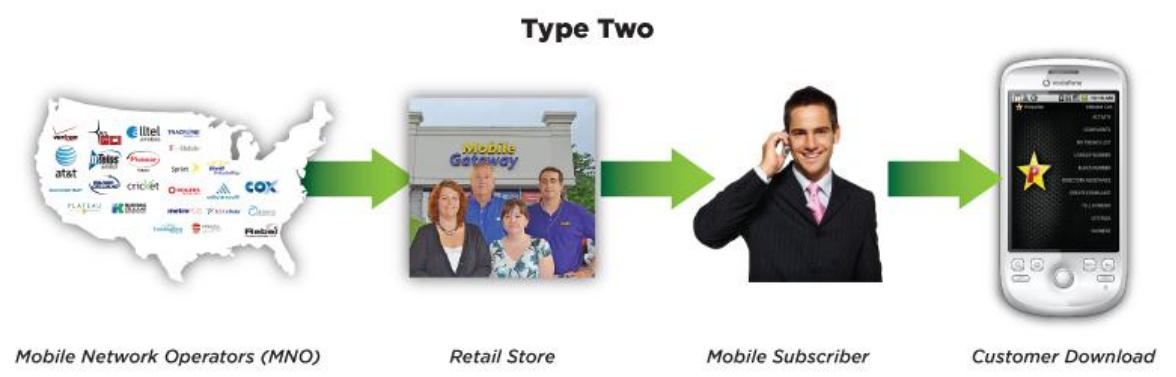

After an intensive planning and sales period, in the fall of 2011 GuardIT contracted with its first mobile network operator (whom we shall call "MNO1") in December of 2011. MNO1 offers service in 19 metropolitan markets and has an estimated 9.4 million subscriber base. According to the reseller agreement, MNO1 subscribers can add the GuardIT blocking utility to their smartphone for $\$ 1.00$ each month. The app can be purchased and downloaded inside the retail store with the help of a sales person while inside the store paying their bill or browsing. At the time of the contract signing, the contracted MNO reports 35 percent of its subscriber base uses smartphones, although this group is growing quickly. In the first phase of the GuardIT roll-out, MNO1 would offer GuardIT to Android 
subscribers only. Per the reseller contract, subscribers opting for the GuardIT app will receive an automatic renewal and not be asked to confirm the monthly charge.

In the reseller arrangement, new customer conversions occur through a combination of the following methods: 1) Subscribing MNO customers visit to the MNO's retail store to browse or pay a bill and are offered the service by a salesperson when they visit the store to pay their bill or 2) subscribers respond to an email, text or print communication campaign from the MNO introducing or endorsing the app and may visit the retail store to get help with the download. A common packaging scenario is for the MNO to incorporate the mobile app as part of a small bundle of apps which may be rolled into a single monthly fee. For example, the MNO may offer a 10-pak app bundle of news and weather, music players and popular games. Users can download these games from the network if they have money in their account or they can activate these apps by calling customer service or visiting the store.

GuardIT's shift in marketing strategy reinforces the notion that strategy is often developing through an iterative, trial and error process. In actuality, the founders were forced to discover the ideal user or true target market for the app only because they were in search of innovative ways to improve acquisition costs. In turn, these series of realizations led the company to a novel distribution channel. In the words of one operations leader in April of 2012,

It's ironic isn't it? The people we thought would want the app the most turned out to be lukewarm about it. The middle market looks like it's going to be our sweet spot. It's funny how off-base we were. The people who are buying it now are people who typically do not even own a credit card. They seem to want it and are even saying they need it. We know now Executives just thought of our app as a 'nice to have' feature on their phone. Huge contrast with the customers we're getting now from (MNO1). These people are saying they have to have it. It keeps the bill collectors away... at least for the months they can pay their cell phone bill. 
In summary, over three phases spanning three calendar years, GuardIT formulated and implemented two distinctly different business models as outlined in the Table 5.3.2 below

Table 5.3.2: Summary of Early (Business Model 1) and Later (Business Model 2) Approaches

\begin{tabular}{|c|c|c|c|}
\hline & \multicolumn{2}{|c|}{ Business Model 1} & Business Model 2 \\
\hline Target Market & \multicolumn{2}{|c|}{$\begin{array}{l}\text { Narrow: } \\
\text { • Price Insensitive Executives }\end{array}$} & $\begin{array}{l}\text { Broad: } \\
\text { • Credit Conscious/ } \\
\text { Cash Only Demographic }\end{array}$ \\
\hline Distribution Structure & Mobile Ad & $\begin{array}{l}\text { App Store } \\
\text { Download }\end{array}$ & $\begin{array}{l}\text { Mobile Network Operator: } \\
\text { - Retail Store Sales Support } \\
\text { - Text Campaigns }\end{array}$ \\
\hline Revenue Model & \multicolumn{2}{|c|}{$\begin{array}{l}\text { Skimming: } \\
\text { - Extended Trial ( } 30 \text { days) } \\
\text { - Higher Monthly Subscription } \\
\text { - Direct Credit Card Billing }\end{array}$} & $\begin{array}{l}\text { Penetration: } \\
\text { - Short Trial (7 days) } \\
\text { - Low Monthly Subscription } \\
\text { - MNO Billing }\end{array}$ \\
\hline
\end{tabular}

\section{Results}

Although skeptics of Business Model 2 adopted in Phase III might question the large revenue-share arrangement, GuardIT is highly encouraged by two factors:

The B2B2C or Reseller Arrangement Lowers Customer Acquisition Costs 20-fold Although the reseller contract designates the MNO gets a 60 cent take on each one dollar of new customer revenue, the customer acquisition cost in this business model remains substantially less for GuardIT than the pricing approach used in Phase I. For one, GuardIT does not incur any outside data costs needed to populate the consumer id knowledgebase since the MNO version of the app is void of the caller id feature. Customers receive the blocking feature only. Furthermore, at the end of Phase II, 
GuardIT determined that targeting consumers directly using mobile advertisements is estimated at a CoCA of $\$ 20.00$ per customer. This figure is in sharp contrast to the reseller partnership where GuardIT's CoCA is $\$ 1.00$. The gap is due in large part to the heavy marketing expenditures, carrier billing fees levied, credit card transaction costs and data costs required to support the caller id offered in the full-featured version of GuardIT. A 'no bells and whistles' or a basic version of the app combined with other cost saving measures, dramatically lowers acquisition cost, making the B2B2C approach a more viable and sustainable business model. (See Table 13 for customer acquisition cost comparisons across each scenario).

Table 6.1 Cost of Customer Acquisition (CoCA) Comparison

\section{Cost of Customer Acquisition (CoCA) Comparison}

\begin{tabular}{|c|c|c|}
\hline & Business Model 1 (B2C) & Business Model 2 (B2B2C) \\
\hline \multicolumn{3}{|l|}{ Koy Data/Assumptions } \\
\hline Cost per Registration & $\begin{array}{r}\$ 2.00 \\
\text { (ad network) }\end{array}$ & $\$ 0.25$ \\
\hline Conversion Rate & $10.0 \%$ & $25 \%$ \\
\hline Cost to Acquire & $35 \%$ related to carrier billing & $\$ 1.00$ \\
\hline Transaction/Payment Costs & Approx. $13 \%$ for $c c$ & $\$ 0.40$ \\
\hline Market Price Point & $\$ 2.99$ & $\$ 1.00$ \\
\hline Net Value to GuardIT & \$ 1.94 & $\$ 0.40$ \\
\hline Avg. Life of Customer & 20 months & 20 months \\
\hline Total Customer Value & $\$ 38.87$ & $\$ 8.00$ \\
\hline 3rd Party Data Costs & $\$ 0.20$ & - \\
\hline 3rd party Data Costs - Life & $\$ 4.00$ & - \\
\hline Estimated Gross Profit & $\$ 14.87$ & $\$ 7.00$ \\
\hline Percent Profit & $38.3 \%$ & $88 \%$ \\
\hline
\end{tabular}

While results from the reseller arrangement are preliminary, the management team is encouraged by the following business results illustrated in 6.2 . 
Table 6.2: Preliminary Results: MNO1 Registrations, Customer Adds and New Totals

\begin{tabular}{llll}
\hline Week & $\begin{array}{l}\text { App trial } \\
\text { registrations from } \\
\text { MNO1 }\end{array}$ & $\begin{array}{l}\text { New GuardIT } \\
\text { customers from } \\
\text { MNO1 }\end{array}$ & $\begin{array}{l}\text { Total Paying } \\
\text { Customers (MNO } \\
\text { and non-MNO) }\end{array}$ \\
\hline In Week2* & 88439 & 35247 & 51211 \\
In Week4 & 72416 & 24316 & 72416 \\
In Week6 & 75276 & 27211 & 93372 \\
\hline
\end{tabular}

*launch figures following a text and email campaign drop to select Android subscribers

The Potential for Competitive Advantage

Another value inherent in B2B2C arrangements is the MNO's potential ability to expand GuardIT's customer base quickly with a relatively small marketing cash outlay for each new customer acquired. These carriers often sell smartphones and flat data plans sold inside the retail store. Here, customers pay bills, learn about new features and upgrade their phone's functionality with the help of sales people on the floor. For these reasons, walk-in subscribers represent a large market potential of new end-users; consumers the app seller would otherwise not be able to reach due to the high costs promotion. Since the competitive landscape for privacy guarding utility apps is fractured, the MNO reseller relationship offers a way for GuardIT to gain marketshare more quickly than its competitors.

The endorsement of a recognized and respected partner can be an extremely valuable stamp of credibility especially for new-to-the-world products. If consumers are hesitant to adopt new types of technologies, these fears may be lessened if the product already has the endorsement of their existing provider. 


\section{Theoretical Contribution}

The evidence from this case study suggests Zott and Amit's theoretical framework for value drivers in ebusiness (2011) can also be applied to digital entrepreneurships in the mobile sector. Our research confirms firms can produce viable businesses by operationalizing one or more of the authors' dimensions (See Figure 3.4.1). In sum, GuardIT's initial business model deployed in Phase I (See Figure 5.3.2) does not conform to any of the four dimensions of which Zott and Amit argue is mandatory for e-business model performance (See Figure 3.4.1). This distribution approach mimics how many app sellers go to market in that it relies heavily on the app store as a major actor in the value chain. Due to marginal financial performance, however, the firm is forced to abandon this popular model after evidence that is unable to produce paying customers at affordable acquisition costs. In contrast, the second business model deployed (Business Model 2 in Phase III) is representative of three of four Amit and Zott dimensions; the Efficiency, Novelty and Complementarities dimensions.

1) For the Efficiencies dimension: business model performance may be enhanced by focusing on customer acquisition costs as a primary factor in overall financial performance. Abandoning mobile advertising and instead selling through resellers enables the firm to lower its overall marketing promotional spend significantly. It enjoys access to a higher number of potential customers for substantially lower fee per transaction. This efficiency, in turn, contributes to a lessened customer acquisition cost which enhances business model performance.

2) For the Novelty dimension: business model performance may be enhanced by forging alliances or reseller arrangements with non-digital retail, physical retail to sell their app. The firm demonstrates a novelty approach by leveraging a partners' physical retail store 
presence to win new customers. Using a nonconventional retail channel gives the digital entrepreneurship access to the partners' wide subscriber base of customers and access to sales people on the retail store floor who may educate them about the new product.

3) For the Complementarities dimension: business model performance may be enhanced if the app seller is part of a larger partner's existing bundle of products and services. The firm may enjoy improved product positioning as part of the resller's existing bundle of endorsed products.

Table 7.3 below compares each business model approach per Zott and Amit's criterion offering at least one attribute that contributes to success.

Table 7.3: Applying Amit and Zott's Value Driver Dimensions to GuardIT Business Models

Efficiency Complementarities Lock-in Novelty

Business

No

No

No

Yes: as first-mover

Model 1

No: as competition

entered

$\begin{array}{lllll}\text { Business } & \text { Yes: lowers } & \text { Yes: GuardIT app becomes } & \text { No } & \text { Yes: using a physical } \\ \text { Model 2 } & \text { CoCa 20- } & \text { part of MNO endorsed } & & \text { retail outlet for sales and } \\ & \text { fold } & \text { bundle } & \text { distribution }\end{array}$

Aside from illustrating how Amit and Zott's value drivers can be applied to small digital entrepreneurships in mobile, this case study also offers insight into how strategy formulation and implementation occur at digital entrepreneurships. Like managers of non-digital firms whose intended business strategy often gets derailed and adjusted in the face of crisis or other information (Mintzberg, 
1976), managers at digital entrepreneurships also deviate from a deliberate strategy when arriving at which course of action to take. At GuardIT, these strategic shifts are most clearly illustrated by the change in the firm's pricing and distribution structure from Phase I to Phase III (see Figure 7.3.4). The intended strategy (B2C) to pull new users through the app store using mobile advertising was eventually abandoned after managers carefully examined problems and tried unsuccessfully to make adjustments. As it became clear to them that customer acquisition cost was a key driver in overall performance, managers designed a new solution; a path to market (B2B2C) using resellers that was never originally intended.

Figure 7.3.4: From an Intended to Realized Strategy

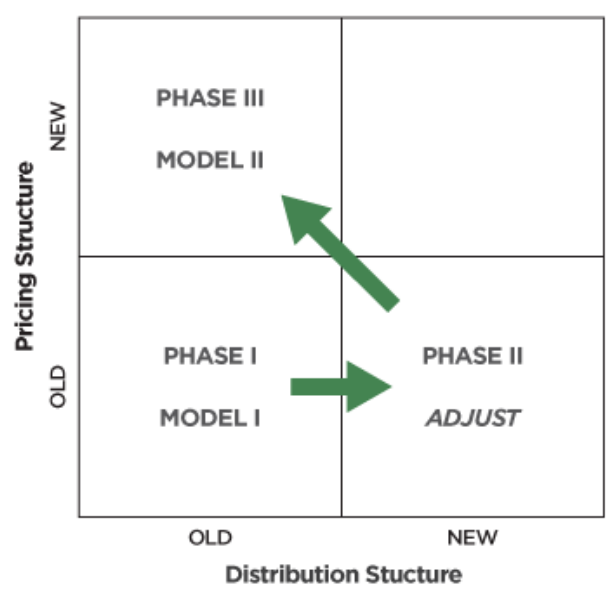

Finally, this case study contributes to the literature on mobile technologies by adding to the dearth of studies on how digital firms are designing and building successful ebuisness models. While the app store is beginning to be addressed in Information Systems (IS) and strategy literature, studies have not yet addressed how mobile application businesses may design sustainable business models when the app store is not a major actor in the value chain. In short, no current studies explore how mobile app sellers may leverage non-digital distribution channels to win customers. We show that despite the 
digital nature of their product, mobile app sellers may benefit from reseller arrangements whereby partners help sell the app through a traditional, physical retail store environment. We show how, by serving in a mobile support services role, the physical retail outlet can earn a place in the mobile value chain.

Finally, this study suggests firms must understand their overall costs of customer acquisition when purchasing display advertising in mobile. Despite the assumption that there is no business risk in purchasing display advertising if it is purchased on a pay-per-performance (eg pay per installation) only basis, we offer evidence to the contrary. The case study suggests the overall effectiveness of mobile display ads to produce profitable customers is contingent on many factors including ad conversion rates (from trial to customer) the end-user's expected retention rate, the price it is charging, and other operational costs such as credit card transaction fees that may be incurred when acquiring a new customer.

\section{Implications}

For practice, our evidence suggests that in a climate of free apps, paid mobile display advertising can be a failed new customer acquisition strategy for start-ups even when the firm is buying mobile ad space on pay-per-performance or pay-for-installation basis. Aside from a keen understanding of customer acquisition costs, the case evidence demonstrates $S_{m} A B s$ must also fully understand the perceived benefits a target market segment is deriving from its product or service and at what price points the segment will accept and continue to use the app.

For app sellers, the business logic behind creating an alternative channel can be summarized as follows: 1) reseller partners are likely more established in the market and offer a large captive base of 
smartphone users who are paying customers; 2) the reseller partner's subscriber has already endorsed the partner as a paying customer thus the $S_{m} A B$ may enjoy favor or higher credibility than its competitors who have no such endorsements; 3 ) the $S_{m} A B$ may be able to leverage the partner's marketing resources and reach; and 4) despite the larger revenue share common to these agreements, a reseller contract structure may still serve to lower the $S_{m} A B$ s individual customer acquisition cost when compared to mobile advertising in a business-to-consumer (B2C) distribution structure.

In non-traditional arrangements, like the one depicted in GuardIT's experience above, established mobile players such as device manufacturers and mobile network operators may reclaim their status as dominant actors in the mobile value ecosystem. Although scholars have noted the app store may be diminishing the mobile network operators' ability to construct walled-garden portals around their subscriber base, this type of business model may serve the small app seller well. App sellers have an alternative to the app store by piggy-backing on the customer-facing position of an established actor. Figure 8.1 below contrasts the app's journey in each discussed scenario. It is important to note the shortened length of the distribution structure in Business Model Two. This study acknowledges that app sellers may also pursue both business model strategies or a hybrid approach simultaneously, although small firms are likely to be too lean in resources to execute both strategies at once. 
Figure 8.1:

Channel Comparison

BUSINESS MODEL ONE

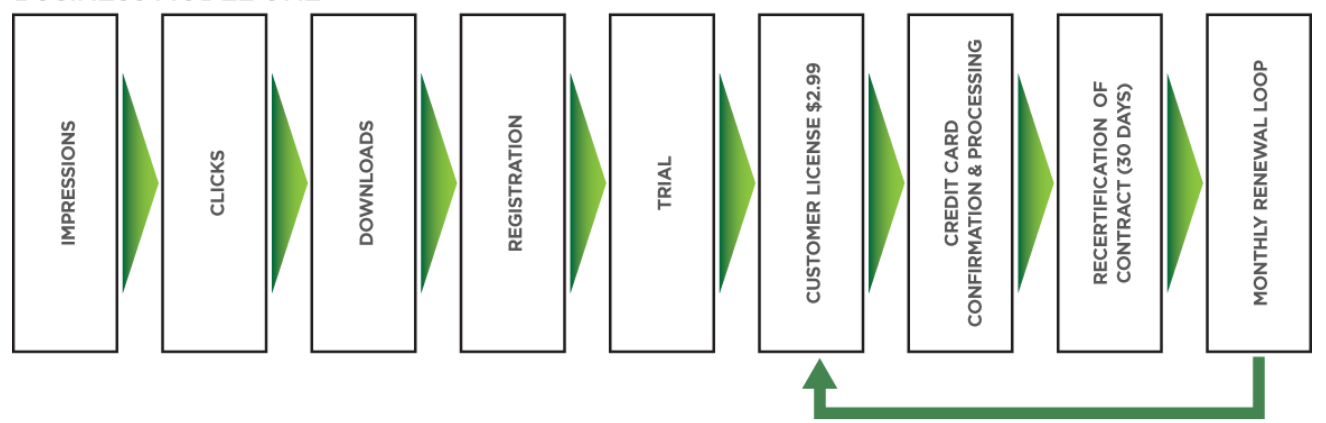

BUSINESS MODEL TWO

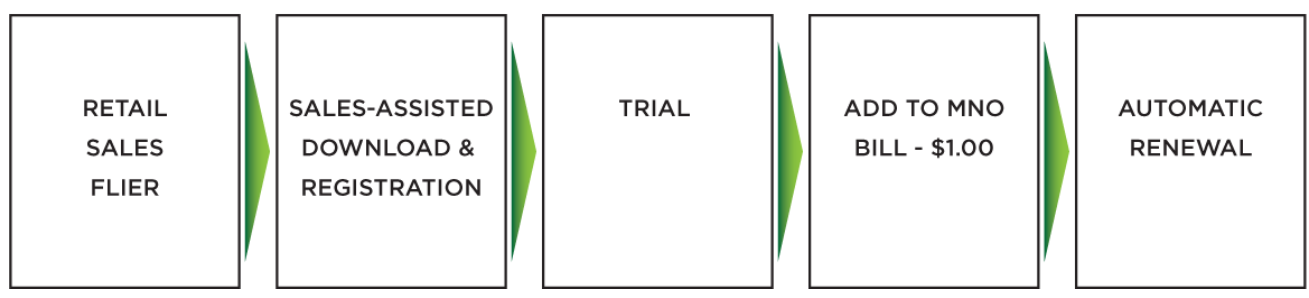

This research identifies several obstacles facing $S_{m} A B$ s in building performing business models and suggests alternative strategies for these companies. This research identified four key considerations facing app sellers as they attempt to build strategies for sustainable business models:

How to Respect the Falling Price of Apps

Although delineations can be made both among app stores and among app categories, it is generally assumed that prices for mobile apps are falling. Microsoft reports the majority of developers submitting apps for approval on the Windows smartphone plan to use the free model with some 68 percent as free downloads, 23 percent paid, and 9 percent paid after the initial free trial period (Microsoft, 2011). Aside from posing threats to the firm's financial viability, the downward market pressure on app pricing also challenges $S_{m} A B$ s to create more perceived value in the eyes of their customers. 
Such downward pressure on app prices is also problematic to app sellers because a) consumers may devalue products when they are free or discounted (Shiv et al, 2005) and b) competitive firms trying to charge for apps may be at a huge disadvantage against others who are charging minimum prices or not charging for their app at all and c) app selling firms, usually lean in resources, must work hard at developing innovative business models which 'disguise' the price of the app. For example, using loss leaders or using paid products to subsidize free apps may work for certain categories of apps in some market landscapes.

This study suggests app sellers may still be able to create viable business models using reseller and other non-digital challenges although the market price is substantially less than their competitors who are selling direct to consumer. Firms must explore alternate arrangements such as the B2B2C approach studied here.

How to Leverage Mobile Network Operators or Other Actors in the Mobile Value Chain Past research has addressed the tendency of established players in the telecommunications industry to erect barriers or walled-garden portals to ensure content creators are kept well away from endcustomers (Peppard \& Rylander, 2006). In the past, carriers and mobile network operators have been considered one of the strongest positions in the mobile value chain because they own the primary relationship with their subscribers (Mennecke \& Strader, 2003). This study suggests ad networks may increasingly occupy positions of similar power in the mobile value chain. These entities erect barriers or walled-garden portals on both sides of the value chain by controlling the sites where the ads are placed and controlling the exchange of information about viewing and performance. 
This study shows, however, that partnering with other established players like moible network operators may give $S_{m} A B$ s alternative choices to market and enable them to be less depemdent on mobile advertising and the app store for customer acquisition. These partnerships or complementarities may actually help small firms in building successful business models by enabling them to scale their business more quickly by offering app sellers efficiences in marketing reach. In turn, carriers or other app resellers benefit from a complementary relationship by offering their subscribers a unique app. App sellers enjoy an alternative to expensive, self-financed mobile advertising campaigns; marketing cooperatives in the partner's retail store or sharing other expenses may enable $S_{m} A B$ s to lower their overall cost of sales.

\section{How to Guard Against Obsolescence}

Most apps have short product life cycles, are used sporadically after download or never downloaded at all. While it is undisputed mobile apps generate great value for consumers (Cortimiglia et al, 2011), it is less clear how $S_{m} A B$ s can address the potentially short life cycle of their product. Other industry research (Flurry, 2010) shows consumers use certain categories of mobile apps regularly but may be very unlikely to keep other types of apps on their device beyond 90 days (See Appendix 1). Productivity apps, for example, like those for list-making or drawing, may offer higher perceived, more sustainable value to consumers. Likewise, these apps are more likely to remain on the handset for a longer period of time. On the other hand, lifestyle or gaming apps like "Fart" and "IQ Test" are a novelty and typically get consumed only a few times before they are discarded (Flurry, 2010).

Although these strategies warrant more research, $S_{m} A B$ s may offer customers more perceived value by offering them innovative ways to access, interact or pay for the product. This study describes one such 
method: by getting the app through a retail store, as our findings suggest, consumers may deem the product more valuable or more reliable than a competitive offering and thus more useful over a longer period of time.

How to Differentiate an App inside a Cluttered App Store

Once a novelty, app stores now contain hundreds of thousands of apps. $S_{m} A B$ s are challenged to devise business strategies which are not dependent on an expanding app store. It has been suggested by mobile analytics firms that although the Apple App Store houses more than 500,000 apps, only apps in the top 25 lists are being downloaded regularly (Adamson, 2012). Thus, getting your app approved in the app store is no longer a means of achieving competitive advantage. Michael Porter predicted technology is relevant to an overall industry structure if technology employed in a value activity becomes widespread. If technology were widespread among rivals, he wrote, technology may actually serve to worsen the industry structure (1986). By lowering barriers to entry for many, then the app store does not give competitive advantage to one firm as once may have been assumed. Instead, the app store may contribute to the demise of profit potential for all app sellers. $S_{m} A B$ s may differentiate their offering by aligning their app with other players like mobile network operators who sell the app through non-digital channels.

\section{Limitations}

Although the findings from this study indicate alternate business models like the one discussed may be applicable to utility apps, it is unclear if app sellers or other categories would be served as well by B2B2C or other nonconventional distribution structures. The studied firm develops, markets and supports a utility app; utility apps are but one of several popular app categories for the smartphone. 
For practitioners, this study is limited to discovering organization's planning and decision-making processes around marketing strategy but does not assist on tactical or organizational challenges related to implementation. 


\section{References}

Adamson, C. (2012, July 31). Two-thirds of iOS Apps are Zombies. Retrieved August, 14, 2012, from http://siliconallee.com/startups/2012/07/31/two-thirds-of-ios-apps-are-zombies-says-apptrace

Afuah, A., \& Tucci, C. (2003). Internet Business Models and Strategies. Boston, Mass.: McGraw-Hill.

Amit R., \& Zott C. (2001). Value creation in e-business. Strategic Management Journal, 22(2), 493520.

Amit R., \& Zott C. (2008). The fit between product market strategy and business model: implications for firm performance. Strategic Management Journal, 29, 1-26. doi: 10.1002/smj.642

Apple (2012). Apple's App Store Downloads Top 25 Billion. [Press Release]. Retrieved from http://www.apple.com/pr/library/2012/03/05Apples-App-Store-Downloads-Top-25-Billion.html

C. Anderson. (2010). Free: How Today's Smartest Businesses Profit by Giving Something for Nothing. New York, NY: Hyperion.

Banerjee, S., \& Dholakia, R. (2008). Mobile advertising: does location based advertising work?. International Journal of Mobile Marketing.

Bauer, H. H., Reichardt, T., Barnes, S.,J., \& Neumann, M. M. (2005). Driving consumer acceptance of mobile marketing: A theoretical framework and empirical study. Journal of Electronic Commerce Research, 6(3), 181-191.

Campbell, P. R. J., \& Ahmed, F. (2011). An assessment of mobile OS-centric ecosystems. Journal of Theoretical and Applied Electronic Commerce Research, 6(2), 50-62

Chatterjee, P. (2008). Are unclicked ads wasted? enduring effects of banner and pop-up ad exposures on brand memory and attitudes. Journal of Electronic Commerce Research, 9(1), 51-61.

Comscore (2011). Digital Omnivores: How Tablets, Smartphones and Connected Devices are Changing US Digital Media Consumption Habits. [PDF]. Available from: Telecomworldwire.

Cortimiglia, M. N., Ghezzi, A., \& Renga, F. (2011). Mobile applications and their delivery platforms. IT Professional Magazine, 13(5), 51-56.

Cortimiglia, M. N., Ghezzi, A., \& Renga, F. (2011). Social applications: Revenue models, delivery channels, and critical success factors - an exploratory study and evidence from the Spanish-speaking market. Journal of Theoretical and Applied Electronic Commerce Research, 6(2), 108-122.

Digital Marketer Predicts Surge in Mobile Advertising (2012). Retrieved January 11, 2012, from: http://www.sfgate.com/cgi-bin/article.cgi?f=/g/a/2012/01/11/prweb9095950.DTL 
Esmaeeli, H. (2011). The study of effecting factors on digital entrepreneurship (A case study).

Interdisciplinary Journal of Contemporary Research in Business, 2(12), 163-172.

Evans, D. S. (2009). The online advertising industry: Economics, evolution, and privacy. The Journal of Economic Perspectives, 23(3), 37-60

Flurry. (2010). Mobile apps: models, money and loyalty. [Blog] Retrieved from http://blog.flurry.com/bid/26376/Mobile-Apps-Models-Money-and-Loyalty

Foley, A., \& Fahy, J. (2009). Seeing market orientation through a capabilities lens. European Journal of Marketing, 43(1), 13-20.

Gartner. (2011). Gartner identifies the top 10 strategic technologies for 2012. [Press Release].

Retrieved from http://www.gartner.com/it/page.jsp?id=1826214.

Gartner (2012.) Gartner Says Worldwide Sales of Mobile Phones Declined 2.3 Percent in Second Quarter of 2012. [Press Release]. Retrieved from http://www.gartner.com/it/page.jsp?id=2120015

Hedman, J., Kalling, T. (2003). The business model concept: theoretical underpinnings and empirical illustrations. European Journal of Information Sciences 12, 49-59.

Haaker, T., Faber, E., Bouwman, H. (2006). Balancing customer and network value in business models for mobile services. International Journal of Mobile Communications 4 (6), 645-661.

Henze, N. (2011). My app is an experiment. [PDF] Retrieved from http://pielot.org/wpcontent/uploads/2011/03/Henze2011-ResearchInTheLarge.pdf.

Holzer \& Ondrus. (2011). Mobile Application Market: a developer's perspective. Telematics and Informatics (28), 22-31

Hong, S., Thong, J. Y., L., Moon, J., \& Tam, K. (2008). Understanding the behavior of mobile data services consumers. Information Systems Frontiers, 10(4), 431-445.

IDC. (2011). Worldwide Smartphone Market Expected to Grow 55\% in 2011 and Approach Shipments of One Billion in 2015, According to IDC. [Press Release]. Retrieved from http://www.idc.com/getdoc.jsp?containerId=prUS22871611.

IDC (2012) Android Expected to Reach Its Peak This Year as Mobile Phone Shipments Slow, According to IDC [Press Release] Retrieved from http://www.idc.com/getdoc.jsp?containerId=prUS23523812

Jayawardhena, C., Kuckertz, A., Karjaluoto, H., \& Kautonen, T. (2009). Antecedents to permission based mobile marketing: An initial examination. European Journal of Marketing, 43(3), 473-499. 
Kallio, J., Tinnila, M., \& Tseng, A. (2006). An international comparison of operator-driven business models. Business Process Management Journal, 12(3), 281-298.

Kenney, M., \& Pon, B. (2011). Structuring the smartphone industry: Is the mobile internet OS platform the key? Journal of Industry, Competition and Trade, 11(3), 239-261.

Kowatsch, T., Maass, W., \& Fleisch, E. (2011). The role of product reviews on mobile devices for instore purchases: Consumers usage intentions, costs and store preferences. International Journal of Internet Marketing and Advertising, 6(3), 226.

Leem CS, Suh HS, \& Kim DS. (2004). A classification of mobile business models and its applications. Industrial Management and Data systems, 104 (1), 78-87.

M, S. (2003). Mobile commerce: technology, theory and applications. Brian E. Mennecke and Troy J. Strader (Eds. ). International Journal of Information Management, 23(4), 357-358. Ideal Group Publishing.

Mintzberg, H., \& Waters, J.,A. (1985). Of strategies, deliberate and emergent. Strategic Management Journal (Pre-1986), 6(3), 257-257.

Ngai, E. W. T., \& Gunasekaran, A. (2007). A review for mobile commerce research and applications. Decision Support Systems, 43(1), 3-3.

Osterwalder, A., \& Pigneur, Y. (2002). An e-business model ontology for modeling e-business. In: 15th Bled Electronic Commerce Conference, Bled, Slovenia. Retrieved from http://www.hec.unil.ch/yp/pub/02-bled.pdf.

Porter, M. (1980). Competitive Strategy: Techniques for Analyzing Industries and Competitors. New York, NY: Free Press.

Rajala, R. \& Westerlund, M.. (2007). Business Models - a New Perspective on Firms' Assets and Capabilities, Observations from the Finnish Software Industry. Entrepreneurship and Innovation, 8(2), 115-126.

Schiff, Allison (2012, June 14). DMA: Direct mail response rates beat digital. DM News. P1.

Rappa, M. (2001). Managing the digital enterprise - Business models on the Web. Retrieved from http://digitalenterprise.org/models/models.html.

Shirky, C., Webber, D., Newcomer, J. M., \& Jaworski, W. M. (1999). USmABility vs. the web. Association for Computing Machinery. Communications of the ACM, 42(3), 27-32.

Shiv, B., Carmon, Z., \& Ariely, D. (2005). Placebo effects of marketing actions: Consumers may get what they pay for. Rochester, NY: Rochester. 
Teece, D. J. (2010). Business models, business strategy and innovation. Long Range Planning, 43(2), 172.

Timmers, P. (1998). Business models for electronic markets. Elecronic Markets 8(2), $2-8$.

University of Maryland. (2011). UMD study finds Facebook applications create more than 182,000 new U.S. jobs worth \$12.19B+ [Press Release]. Retrieved from http://www.prnewswire.com/newsreleases/umd-study-finds-facebook-applications-create-more-than-182000-new-us-jobs-worth-1219b130112813.html.

Wortham, J. (2009, June 7). Apps Are Booming as Companies Seek a Place on Your Phone. New York Times, p. B4.

Wortham, J. (2012, April 10). A Billion-Dollar Turning Point for Mobile Apps. New York Times, p. A1.

Yip, G. (2004). Using Strategy to Change Your Business Model. Business Strategy Review, 15(2).

Saletan, W. (2001, October 17). The power of negative thinking. Slate. Retrieved October 20, 2001, from 
Exhibit 1: Ad Network Reporting Sample of Campaign Performance

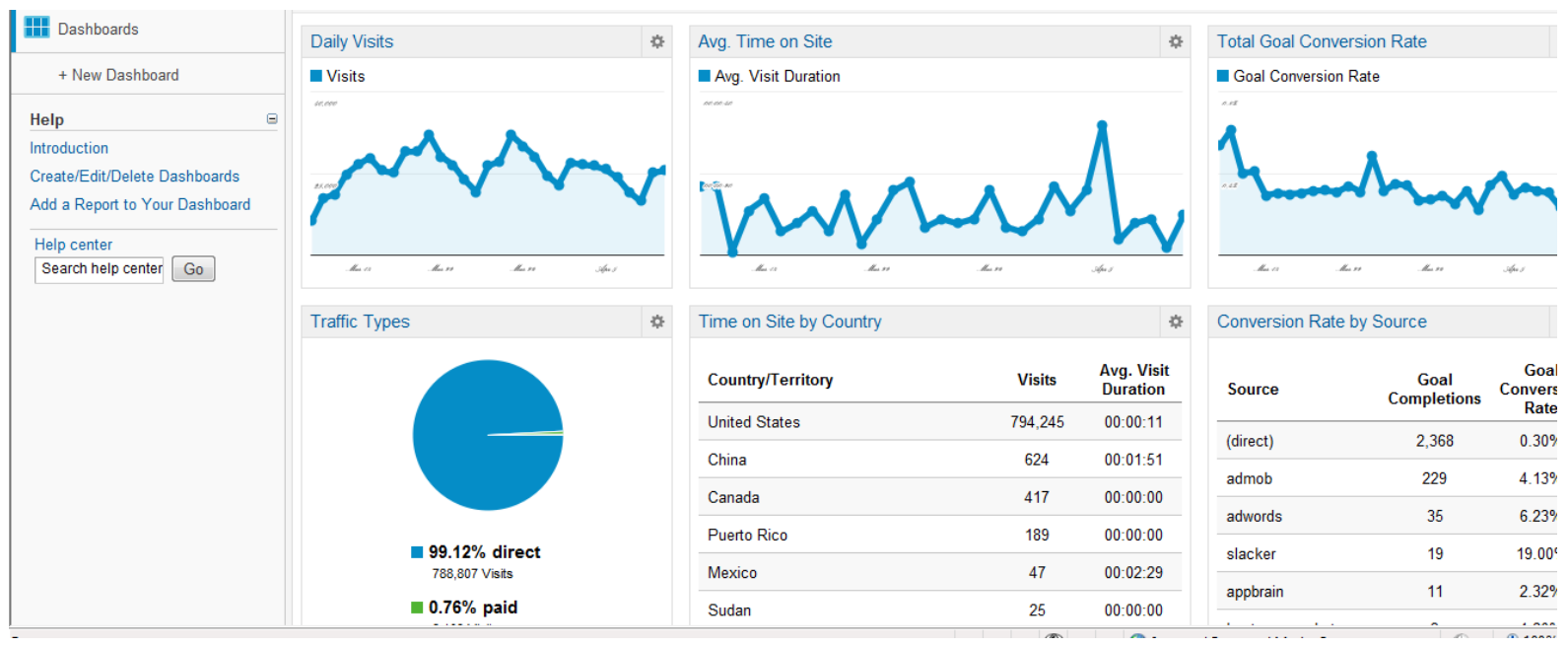

Exhibit 2: Dashboard from GoogleAnalytics

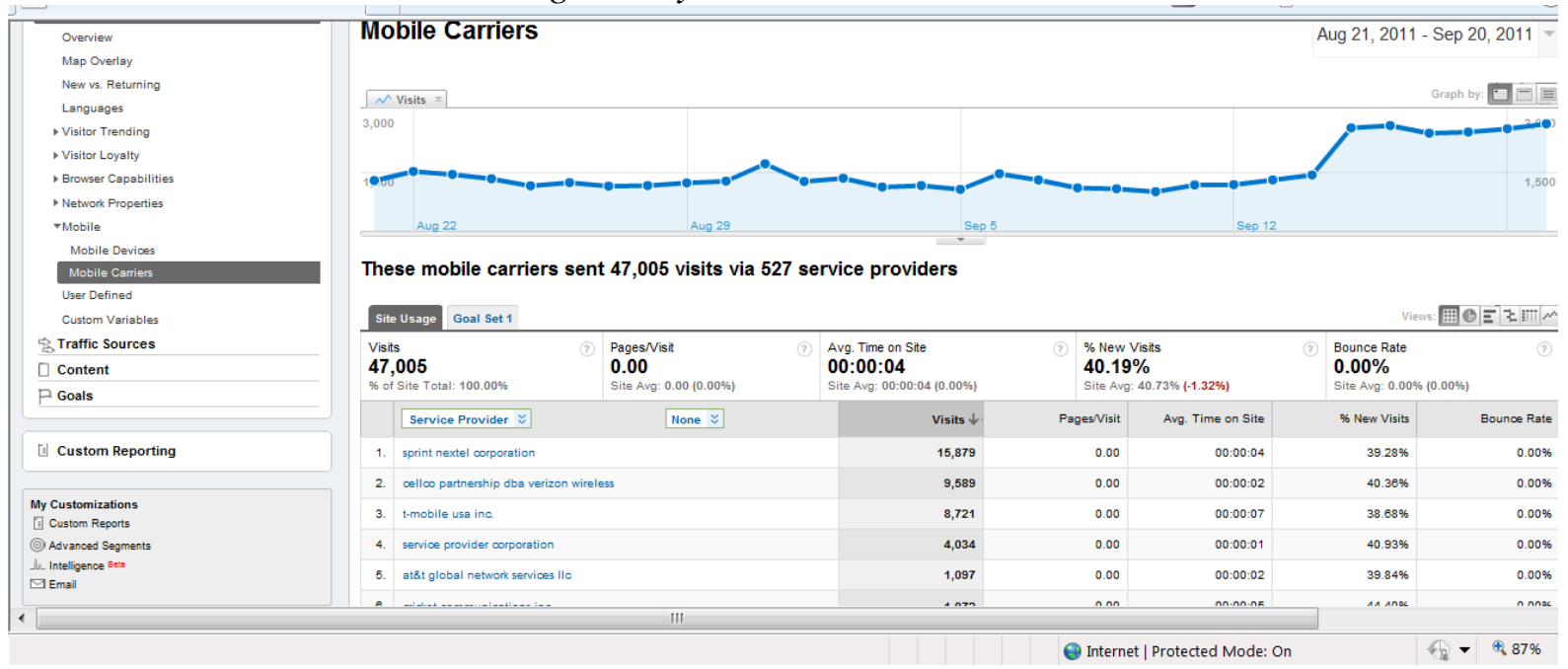


Appendix 1: App Retention by Category

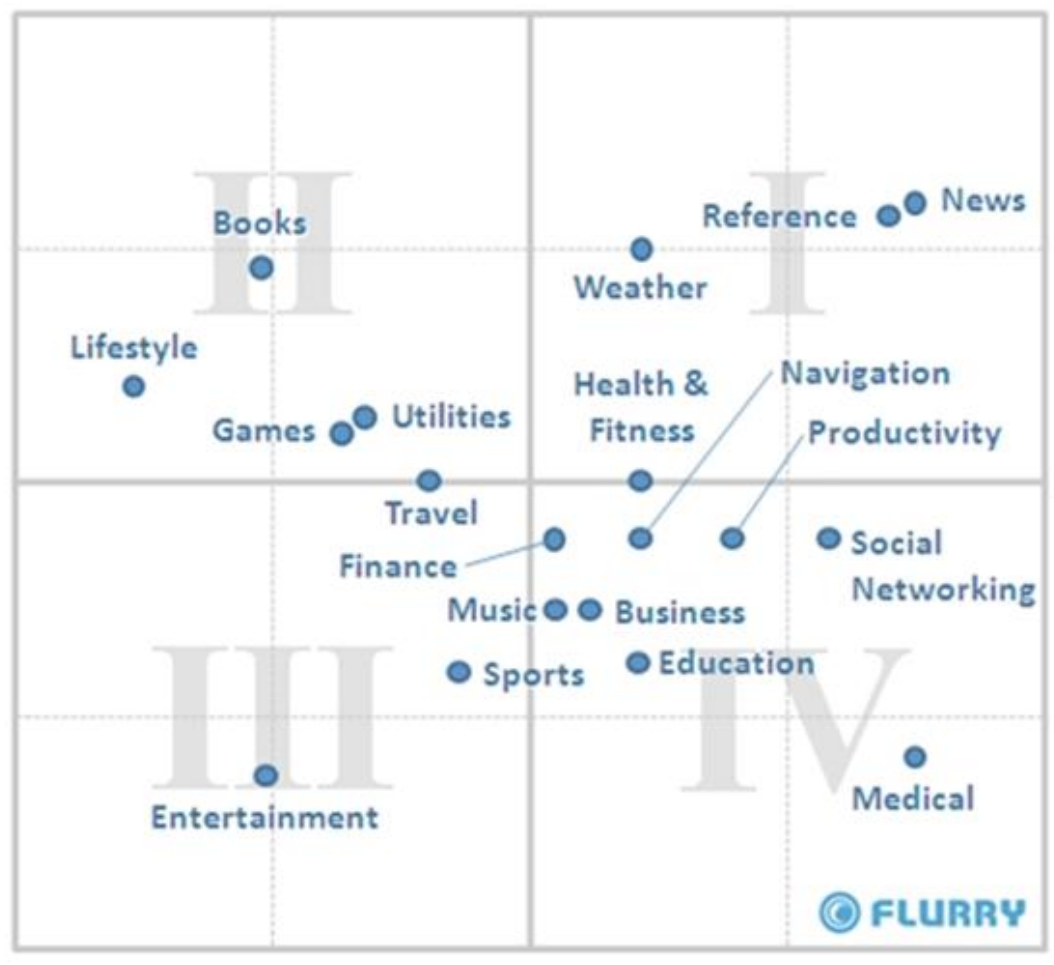

Source: Flurry, 2010 


\section{Vitae}

Professional experience includes 21 years high-tech, business-to-business marketing in the areas of Interactive Marketing, Strategic Planning, Marketing Communications and Public Relations.

\section{Academic Teaching Experience}

College of Business \& Economics

Hendrix College

1600 Washington Avenue

Conway, Arkansas 72032

College of Business

University of Arkansas at Little Rock

2801 S. University Avenue

Little Rock, Arkansas 72204
Visiting Professor (since 2001)

Marketing Instructor (since 2007)

\section{Education}

Executive Doctorate of Business:

Master of Science (Marketing):

Bachelor of Arts (French):
Georgia State University (May, 2012)

Georgia State University (March, 1996)

Georgia State University (December, 1990)

\section{Recent Professional Experience}

\section{4 - 2008: Chief Marketing Officer, Querencia Club \& Properties, Los Cabos, Mexico}

Collaborated with executive team to create and execute all-points marketing plan and supporting budget for each year. Activities include: designed and managed company's interactive marketing strategy including the original build and weekly maintenance of the corporate website. Guided team to develop supplemental Members' Only intranet portal for tournament registrations, season calendars, surveys, and photo galleries. Managed monthly search engine marketing budget and key words (Yahoo, AOL \& Google AdWords). Responsible for traffic analysis/conversions using Google Analytics. Wrote, ghost-wrote and disseminated weekly email campaigns to all customer, prospects and other list segments using Constant Contact. Managed search and selection process for creative, PR and interactive agencies. Worked with agencies to place insertions and special campaigns in national publications such as WSJ, USA Today, Golf Digest, Variety and Robb Report. Produced award-winning corporate DVD for use in multiple sales and marketing venues. Led firm's international public relations efforts. Produced sales collateral for all print and digital venues including real estate property brochures, monthly newsletters and special events promotions. Devised corporate communications standards. Trained associates on policies for usage in retail, dining and all print environments. 
1999 - 2004: Director of Marketing, CognitiveDATA (now Merkle, Inc.)

Oversaw web site development and maintained digital web content and digital communications activities for company. Launched the IntelliDress family of brands: logo/naming, positioning, optimal product feature set and promotion strategy. Public Relations: formed media relationships to secure speaker engagements at industry tradeshows. Pitched company for third party awards and external recognition (WSJ, Deloitte \& Touche, DMA, \& Inc. Magazine's Fastest Growing Companies in the US). Negotiated reseller relationships with wholesalers and third parties. Business Development Activities: conducted market research for prospecting, developed sales presentations, wrote initial series of company white papers and customer testimonials. Hired product and marketing communications personnel to support a growing business.

\section{Papers Presented at Professional Meetings}

American Marketing Association Summer 2011 Educators' Conference:

Pascal's Wager: The Promised or Delivered Benefits of Brand-Sponsored Virtual Brand Communities

\section{Research Interests}

Online Advertising Effectiveness for Mobile Devices

Business Strategy Development in Digital Entrepreneurships

Electronic Word of Mouth (EWOM) Brand Recommendations in Virtual Brand Communities and Social Networking Sites 